\title{
GENERAL PB-ISOTOPE SYSTEMATICS OF SOURCES FOR VOLCANIC ROCKS OF THE LATEST GEODYNAMIC STAGE IN ASIA
}

\author{
S. V. Rasskazov ${ }^{1,2}$, I. S. Chuvashova ${ }^{1,2}$, T. A. Yasnygina', \\ Yi-min Sun ${ }^{3}$, E. V. Saranina ${ }^{1}$ \\ ${ }^{1}$ Institute of the Earth's Crust, Siberian Branch of RAS, Irkutsk, Russia \\ ${ }^{2}$ Irkutsk State University, Irkutsk, Russia \\ ${ }^{3}$ Institute of Volcano and Mineral Spring, Heilongjiang Academy of Science, \\ Wudalianchi, Heilongjiang, China
}

\begin{abstract}
The modern theory of the evolving Earth is based on integrated isotopic data obtained for the accessible part of the planet and cosmic bodies, in which the $\mathrm{U}-\mathrm{Pb}$ isotope system plays a key role. The theory is tested by the isotope systematics of oceanic basalt sources. The origin of continental volcanic rocks is often interpreted in terms of the isotopic systematics of oceanic basalts. However, such interpretations, as a rule, reveal contradictions arising from differences in the history and current mantle dynamics of oceans and continents. Under the oceans, a mantle material has long lost connection with the accessible Earth tectonic units; under the continents such a connection is often established. The nature of the evolution of deep-seated processes under the continents remains uncertain and, by analogy with the oceans, requires deciphering in terms of the components of the mantle sources for volcanic rocks. In modern lithospheric plates of the Earth, there are regions ranging in width from hundreds to thousands of kilometers, which are characterized by high strain rates and, consequently, at least one to two orders of magnitude lower viscosity relative to that of the internal stable parts of the plates. This gives them a special structural status of "dispersed plate boundaries". The isotope-geochemical studies of volcanic rocks from regions of the unstable Asia revealed the different nature of components in sources, for which particular interpretations have been proposed. In this paper, a general systematics of sources is defined for volcanic rocks of the latest geodynamic stage in Asia through estimating the incubation time on the ${ }^{207} \mathrm{~Pb} /{ }^{204} \mathrm{~Pb}$ versus ${ }^{206} \mathrm{~Pb} /{ }^{204} \mathrm{~Pb}$ diagram. Two domains are designated: (1) low ${ }^{238} \mathrm{U} /{ }^{204} \mathrm{~Pb}$ (LOMU) derived from the viscous protomantle (VIPMA), and (2) elevated ${ }^{238} \mathrm{U} /{ }^{204} \mathrm{~Pb}$ (ELMU). The mantle domains evolved from the Earth's primary material between 4.51 and 4.36 Gyr ago, 4.0 and 3.7 Gyr ago, 2.9 and 2.6 Gyr ago, 2.0 and 1.8 Gyr ago, about 0.66 Gyr ago and $<0.09$ Gyr ago. Melting anomalies of ELMU sources characterize the unstable mantle of Southern Asia, and those of LOMU sources belong to the Japan-Baikal geodynamic corridor of the transitional region between the unstable mantle of Asia and its stable core. The Late Cenozoic evolution of the Japan-Baikal geodynamic corridor resulted in cutting the LOMU domain by the Jeju-Vitim ELMU source line.
\end{abstract}

Key words: volcanic rocks; Pb isotopes; latest geodynamic stage; geodynamic corridor; Asia

RESEARCH ARTICLE

Received: March 22, 2019

Revised: May 17, 2019

Accepted: May 23, 2019

For citation: Rasskazov S.V., Chuvashova I.S., Yasnygina T.A., Yi-min Sun, Saranina E.V., 2019. General Pb-isotope systematics of sources for volcanic rocks of the latest geodynamic stage in Asia. Geodynamics \& Tectonophysics 10 (2), 507-539. doi:10.5800/GT-2019-10-2-0424. 


\title{
ГЕНЕРАЛЬНАЯ РЬ-ИЗОТОПНАЯ СИСТЕМАТИКА ИСТОЧНИКОВ ВУЛКАНИЧЕСКИХ ПОРОД НОВЕЙШЕГО ГЕОДИНАМИЧЕСКОГО ЭТАПА АЗИИ
}

\author{
С. В. Рассказов ${ }^{1,2}$, И. С. Чувашова ${ }^{1,2}$, Т. А. Ясныгина1, \\ Йи-минь Сунь ${ }^{3}$, Е. В. Саранина ${ }^{1}$
}

${ }^{1}$ Институт земной коры СО РАН, Иркутск, Россия

${ }^{2}$ Иркутский государственный университет, Иркутск, Россия

${ }^{3}$ Институт вулканов и минеральных источников Хэйлунцзянской академии наук, Удаляньчи, Хэйлунцзян, Китай

\begin{abstract}
Аннотация: Современная теория эволюционирующей Земли основана на комплексных изотопных данных о доступной для опробования части планеты и космических телах, в которых ключевую роль играют построения в U-Pb изотопной системе. Теория тестируется разработанной изотопной систематикой источников океанических базальтов. Происхождение вулканических пород континентов часто трактуется в терминах изотопной систематики океанических базальтов. Однако такие интерпретации, как правило, содержат противоречия, вытекающие из различий истории становления и ныне существующих различий в динамике мантии океанов и континентов. Под океанами мантийный материал давно утратил связь с поверхностными структурами Земли; под континентами такая связь нередко устанавливается. Характер эволюции глубинных процессов под континентами остается неопределенным и, по аналогии с океанами, требует расшифровки в терминах компонентов мантийных источников вулканических пород. В современных литосферных плитах Земли различаются области шириной от сотен до тысяч километров, характеризующиеся высокой скоростью деформаций и, следовательно, по меньшей мере, на один - два порядка пониженной вязкостью относительно внутренних стабильных частей плит, что придает им особый структурный статус «рассеянных плитных границ». Изотопно-геохимические исследования вулканических пород регионов нестабильной Азии выявили различный характер компонентов источников, для которых были предложены частные интерпретации. В настоящей работе определяется генеральная систематика источников вулканических пород новейшего геодинамического этапа Азии по оценке времени инкубации их материала на диаграмме $207 \mathrm{~Pb} / 204 \mathrm{~Pb}-206 \mathrm{~Pb} / 204 \mathrm{~Pb}$. Обозначаются два домена: один - с низким $238 \mathrm{U} / 204 \mathrm{~Pb}$ (LOMU), производный вязкой протомантии (VIPMA), другой - с повышенным ${ }^{238} \mathrm{U} /{ }^{204} \mathrm{~Pb}$ (ELMU). Мантийные домены эволюционировали от первичного материала Земли во временных интервалах 4.51-4.36 млрд лет назад, 4.0-3.7 млрд лет назад, 2.9-2.6 млрд лет назад, 2.0-1.8 млрд лет назад, около 0.66 млрд лет назад и <0.09 млрд лет назад. Расплавные аномалии источников ELMU характеризуют нестабильную мантию Южной Азии, расплавные аномалии источников LOMU - мантию Японско-Байкальского геодинамического коридора области перехода от нестабильной мантии Азии к ее стабильному ядру. Позднекайнозойская эволюция Японско-Байкальского геодинамического коридора привела к рассечению домена LOMU Чеджу-Витимской линией источников ELMU.
\end{abstract}

Ключевые слова: вулканические породы; изотопы $\mathrm{Pb}$; новейший геодинамический этап; геодинамический коридор; Азия

\section{1. ВВЕДЕНИЕ}

Континентальные и океанические сегменты современной Земли имеют разный возраст: континентальная литосфера сложена породами, охватывающими всю ее историю, океаническая - историю последних 280 или 180 млн лет [Sandwell et al., 2005; Müller et al., 2008]. Принятая в настоящее время геологическая парадигма тектоники литосферных плит основана на результатах исследований океанов в терминах изотопных компонентов вулканических пород и моделей сейсмической томографии. Предполагается активность ма- логлубинных мантийных источников, сочетающаяся со спредингом океанического дна, а также активность глубинных источников, выраженная в горячих мантийных струях (плюмах) [Morgan, 1971; Sobolev et al., 2005; Zhao, 2009; White, 2015; Dickin, 2018].

Океанические базальты чаще всего классифицировались в терминах конечных глобальных $\mathrm{Pb}-\mathrm{Sr}-$ Nd-изотопных компонентов EM1, EM2, HIMU и DMM (соответственно, компоненты обогащенной мантии 1 и 2, компонент с высоким ${ }^{238} \mathrm{U} /{ }^{234} \mathrm{~Pb}(\mu)$ и обедненный компонент). Предполагалось рециклирование материала базальтов океанических ост- 
ровов (ОIB) в океаническую мантию посредством субдукции 3-2 млрд лет назад [Zindler, Hart, 1986]. Во многих океанических плюмах отмечалась примитивная составляющая, проявившаяся прежде всего в изотопных отношениях благородных газов [Allègre, 2008; Parman, 2007; White, 2015]. Обращалось внимание на обособленное положение резервуара DMM, обозначающего MORB, относительно других резервуаров в координатах изотопных отношений $\mathrm{Pb}$ и Os и на сложную эволюцию резервуapa DMM, который по этой причине исключался из обсуждения компонентного состава ОІВ как производного валового состава Земли [Hauri et al., 1994; Murphy et al., 2003].

Происхождение источников вулканических пород континентов нередко трактовалось в терминах изотопной систематики океанических базальтов. Однако такие интерпретации, как правило, содержали противоречия, вытекающие из различий истории становления и ныне существующих различий в динамике мантии океанов и континентов. Под океанами мантийный материал давно утратил связь с поверхностными структурами Земли, под континентами, например, такая связь устанавливается на западе Северной Америки [Menzies, 1990]. Под океанами выражена мантийная конвекция, движущая литосферные плиты, под континентами мантийная конвекция имеет ограниченное распространение или отсутствует. Характер эволюции глубинных процессов под континентами остается неопределенным и, по аналогии с океанами, требует расшифровки в терминах компонентов мантийных источников вулканических пород.

В современных литосферных плитах Земли различаются области шириной от сотен до тысяч километров, характеризующиеся высокой скоростью деформаций и, следовательно, по меньшей мере, на один - два порядка пониженной вязкостью относительно внутренних стабильных частей плит, что придает им особый структурный статус «рассеянных плитных границ» [Sengör, Natal'in, 1996; Zatman et al., 2005; Yoshida, 2010; Yoshida, Santosh, 2011]. Обширная подвижная область ограничивает с юго-востока стабильную Северо-Евразийскую плиту [Molnar, Tapponier, 1975; Kreemer et al., 2003; Gatinskii, Rundquist, 2004]. Юго-восточная подвижная часть Евразии переходит в ее стабильную часть через Японско-Байкальский геодинамический коридор - ограниченную по латерали подвижную полосу литосферы и подлитосферной мантии, подверженную воздействию сил затягивания материала от ее периферии к оси. Ось коридора протягивается от спредингового сегмента океанической коры Японского моря к центру Байкальской рифтовой системы. Кроме силового поля геодинамического коридора, на Азию воздействовало также другое силовое поле, обусловленное ее конвергентным взаимодействием с Индостаном. Конвергенция отразилась в развитии литосферных структур юго-юго-западного фланга геодинамического коридора и не оказала заметного влияния на развитие структуры литосферы северо-северо-восточного фланга [Chuvashova et al., 2017b].

Территория Азии была ареной вулканизма новейшего геодинамического этапа, охватившего последние 90 млн лет [Rasskazov, Chuvashova, 2013, 2018]. Об источниках ее вулканизма высказывались различные суждения [Tatsumi et al., 1990; Zonenshain et al., 1991; Maruyama et al., 2007; и дp.]. Изотопногеохимические исследования вулканических пород отдельных регионов [Chandrasekharam et al., 1999; Chen et al., 2007; Choi et al., 2006; Kuritani et al., 2013; Melluso et al., 2006; Park et al., 2005; Peng et al., 1994; Rasskazov, Chuvashova, 2018; Rasskazov et al., 2002, 2005, 2014, 2019; Song et al., 1990; Tatsumi et al., 2005; Tatsumoto et al., 1992; Wee, 1999; Zartman et al., 1991; Zhang et al., 1995, 2018; Zhang, Guo, 2016; Zou et al., 2000] выявили различный характер компонентов источников, для которых были предложены частные интерпретации. Излившиеся мантийные расплавы контаминированы коровым материалом лишь в исключительных случаях, что открывает возможность исследования характера мантийных источников. Цель настоящей работы - определить критерии их генеральной систематики.

\section{2. Подходы}

В одной из ранних работ, исходя из изотопных отношений $\mathrm{Pb}, \mathrm{Nd}$ и $\mathrm{Sr}$, A.P. Базу и др. [Basu et al., 1991] предположили, что калиевые вулканические породы поля Удаляньчи характеризуют компонент EM1 OІВ и являются материалом континентальной литосферной мантии, а калинатровые базальты других территорий Северо-Восточного Китая представляют собой материал, включающий компонент DMM OIB, производный астеносферной мантии. По гипотезе этих авторов, астеносфера вторгалась в литосферную мантию в результате тектонических процессов в зоне субдукции, ассоциирующейся с магматизмом Японских островов. В этой гипотезе в качестве ведущего процесса признавалось декомпрессионное плавление литосферной мантии, которое осложнялось образованием расплавов, производных источников субдуцированной океанической коры. Подобная гипотеза принималась для объяснения происхождения выплавок полей Удаляньчи, Еркешан и Келуо (зоны WEK) с допущением постархейского возраста источника континентальной мантии, подобного EM1 OIB [Zhang et al., 1995]. 
Указание на сходство состава пород архейской континентальной литосферы с компонентом EM1 OIB и на соответствие состава пород верхней части коры компоненту EM2 OIB [Menzies, 1990] внесло путаницу в систематику континентальных вулканических пород. Во многих опубликованных работах источник калиевых пород Удаляньчи был принят в качестве аналога источника океанических базальтов EM1 OIB. Заметим, однако, что по Lu-Hf-изотопной систематике происхождение этого конечного компонента ОІВ связывается с рециклированием глубоководных осадочных отложений. Компоненты континентальной мантии или коры в состав EM1 OІB не входят [Dickin, 2018]. Предположение о происхождении калиевых пород Удаляньчи из источника континентальной литосферы, сходного с источником океанических базальтов EM1 OIB, в сущности, заключало в себе внутреннее противоречие.

После выделения общих компонентов FOZO (Focal Zone) и C (Common) по сходящимся трендам точек на диаграммах разных изотопных отношений океанических базальтов [Hauri et al., 1994; Hannan, Graham, 1996] такой же подход реализовался для выделения общих компонентов континентальных базальтов в масштабе отдельных регионов Азии. Так, в позднекайнозойских щелочных базальтах, излившихся на восточной континентальной окраине Китая, по изотопным отношениям $\mathrm{Nd}, \mathrm{Sr}$ и $\mathrm{Pb}$ был выведен общий обедненный (относительно валового состава силикатной Земли) подлитосферный компонент, сочетающийся с литосферными компонентами-примесями [Zou et al., 2000]. Подчеркивалось соответствие микроэлементных характеристик базальтов (обеднение свинцом, обогащение ниобием и танталом, высокие отношения $\mathrm{Ce} / \mathrm{Pb}, \mathrm{Nb} / \mathrm{U}$ и низкое отношение $\mathrm{La} / \mathrm{Nb}$ ) характеристикам базальтов океанических островов. В этой систематике единый компонент обедненной подлитосферной мантии территории был обозначен лавами вулканов Ташан (возраст 16.3 млн лет), Нушан (возраст 0.55-0.72 млн лет) и Фангшан (возраст 9.1-9.4 млн лет). Исходя из отличия континентальной литосферы северо-востока и юговостока Китая, предполагалось смешение общего подлитосферного компонента в базальтах СевероВосточного Китая с компонентом обогащенной литосферной мантии, подобной EM1 OIB (с низким $\left.{ }^{206} \mathrm{~Pb} /{ }^{204} \mathrm{~Pb}\right)$, а в базальтах Юго-Восточного Китая с компонентом обогащенной литосферной мантии, подобной EM2 OIB (с высоким ${ }^{206} \mathrm{~Pb} /{ }^{204} \mathrm{~Pb}$ ). Крайнее положение компонента EM1 OІB занимали лавы вулканического поля Удаляньчи (возраст $<2.5$ млн лет), а компонента ЕМ2 ОIВ - лавы Ниутуо (возраст 17.9-16.7 млн лет).

Предлагались другие систематики, включающие компоненты океанических базальтов. К примеру, по изотопным отношениям $\mathrm{Sr}-\mathrm{Nd}-\mathrm{Pb}-\mathrm{Hf}$ в вулканических породах восточной окраины Азии обозначались два домена, в одном из которых (СинМенг) источники относились к астеносфере, состоящей из смеси компонентов DMM OIB и EM1 OIB, в другом (Южно-Китайском) - к астеносфере, состоящей из смеси компонентов DMM OIB и EM2 OIB [Choi et al., 2006]. В другой работе допускалось смешивание конечного члена FOZO OIB с конечным членом LoMu, который относился к континентальной литосфере [Chen et al., 2007].

На территории Внутренней Азии, в вулканических породах Восточного Саяна, был выделен общий обедненный (относительно валового состава Земли) компонент: ${ }^{87} \mathrm{Sr} / 86 \mathrm{Sr}=0.7041, \varepsilon \mathrm{Nd}=+3$, ${ }^{206} \mathrm{~Pb} /{ }^{204} \mathrm{~Pb}=18.1-18.2,{ }^{207} \mathrm{~Pb} /{ }^{204} \mathrm{~Pb}=15.53,{ }^{208} \mathrm{~Pb} /{ }^{204} \mathrm{~Pb}=$ $=38.2$ [Rasskazov et al., 2002]. По изотопным отношениям $\mathrm{Nd}$ и $\mathrm{Sr}$ пород различных вулканических полей Центральной Монголии были рассчитаны тренды смешения компонентов с обогащенными и обедненными характеристиками и выявлены пространственные изменения геохимических характеристик, свидетельствующие о латеральной смене источников. Общий компонент, подобный общему компоненту базальтов Восточного Саяна, был обозначен в вулканических породах западной части Витимского вулканического поля, но не был идентифицирован в его восточной части [Rasskazov, Chuvashova, 2018]. На востоке Азии, в тыловой области дуги Северо-Восточного Хонсю, была выявлена смена компонентного состава вулканических пород в последние 37 млн лет и особо отмечены породы возрастного интервала 30-20 млн лет с общим компонентом, имевшим региональное значение для расплавных аномалий южного субдомена Забайкальского домена: ${ }^{87} \mathrm{Sr} /{ }^{86} \mathrm{Sr}=0.7052, \quad{ }^{206} \mathrm{~Pb} /{ }^{204} \mathrm{~Pb}=17.55, \quad{ }^{207} \mathrm{~Pb} /{ }^{204} \mathrm{~Pb}=$ $=15.52,{ }^{208} \mathrm{~Pb} /{ }^{204} \mathrm{~Pb}=37.76$. Этот специфичный общий компонент проявился в вулканических породах континентальной окраины до позднекайнозойской субдукции Тихоокеанского слэба. Субдукция началась с оформления зональности надсубдукционного вулканизма дуги Северо-Восточного Хонсю около 18 млн лет назад. Выплавки с обедненными изотопными характеристиками слэба получили развитие в тылу дуги только в интервале 15-6 млн лет назад. Роль обедненных изотопных выплавок возросла в последние 4.4 млн лет [Rasskazov et al., 2005, 2014].

Общие изотопные компоненты молодых вулканических пород обозначались и в других регионах Евразии. К примеру, для траппов плато Декан определялась общая характеристика (common signature): $\varepsilon \mathrm{Nd}=\sim+5,{ }^{206} \mathrm{~Pb} /{ }^{204} \mathrm{~Pb}=\sim 18$ [Peng et al., 1994; Melluso et al., 2006]. Для кайнозойских анорогенных вулканитов Средиземноморья и со- 
предельных территорий обозначался общий мантийный резервуар (Common Mantle Reservoir): ${ }^{87} \mathrm{Sr} /{ }^{86} \mathrm{Sr}=0.7030-0.7036, \varepsilon \mathrm{Nd}=+2.5 \ldots+5.5,{ }^{206} \mathrm{~Pb} /{ }^{204} \mathrm{~Pb}=$ $=19.6-19.9,{ }^{207} \mathrm{~Pb} /{ }^{204} \mathrm{~Pb}=15.60-16.66$ [Granet et al., 1995; Lustrino, Wilson, 2007].

В общих компонентах вулканических пород разных регионов мира подчеркивалась местная специфика источников. Интегральное использование $\mathrm{U}-\mathrm{Pb}$ и других ( $\mathrm{Rb}-\mathrm{Sr}, \mathrm{Sm}-\mathrm{Nd}, \mathrm{Lu}-\mathrm{Hf})$ изотопных систем не дало общей классификационной схемы континентальных вулканических пород, подобной схеме конечных компонентов базальтов океанов. Обширный массив опубликованных изотопных данных по континентальным вулканическим породам, в сущности, не приведен к общему показателю. Учитывая несоответствие $\mathrm{Pb}$-изотопных и Sr-Nd-Hf-изотопных данных, обусловленное контрастными эффектами концентрирования $\mathrm{Pb}$ в сульфидах и $\mathrm{Sr}-\mathrm{Nd}-\mathrm{Hf}$ - в силикатах [Allègre et al., 1982; Albarède, 2009; Murphy et al., 2003; Hart, Gaetani, 2006], в настоящей работе мы определяем источники вулканических пород Азии в ходе эволюции Земли в рамках ${ }^{207} \mathrm{~Pb}-206 \mathrm{~Pb}$-изотопной систематики как первой (генеральной) ступени разделения всей совокупности данных. Другие изотопные показатели и элементные отношения вулканических пород предполагается использовать для расшифровки второстепенных трендов компонентов мантии и коры Азии на второй и последующих этапах анализа источников вулканических пород. Эти этапы здесь не рассматриваются.

\section{3. ОЦЕНКИ ИНКУБАЦИИ МАТЕРИАЛА МАНТИЙНЫХ ИСТОЧНИКОВ ВУЛКАНИЧЕСКИХ ПОРОД}

Генетическая общность материала источника предполагает изохронные соотношения между компонентами. Полная изотопная гомогенизация источника, выводящая радиоизотопную систему на начальное отношение, может достигаться в результате плавления и конвективного перемешивания материала и/или в результате метасоматоза. Время инкубации и характер материала глубинного источника вулканических пород оцениваются по распределению фигуративных точек на диаграмме изотопных отношений ураногенного $\mathrm{Pb}$ $\left({ }^{207} \mathrm{~Pb} /{ }^{204} \mathrm{~Pb}-206 \mathrm{~Pb} /{ }^{204} \mathrm{~Pb}\right)$. Материнские изотопы ${ }^{238 \mathrm{U}}$ и ${ }^{235} \mathrm{U}$, дочерние изотопы ${ }^{206} \mathrm{~Pb}$ и ${ }^{207} \mathrm{~Pb}$ в любых геологических средах кинетически неразделимы между собой, поэтому по изохронным соотношениям изотопов $\mathrm{Pb}$ извергнутые вулканические породы интерпретируются как результат глубинного плавления одновозрастного субстрата. Если магматический расплав отделяется от гомогенного источни- ка, совокупность точек диаграммы изотопных отношений ураногенного $\mathrm{Pb}$ образует компактное изометричное фигуративное поле. Вся изохронная информация о предшествующей истории материала такого источника стирается. Изотопная характеристика свидетельствует о современном гомогенном состоянии материала. Дифференциация источника по значениям ${ }^{238} \mathrm{U} /{ }^{204} \mathrm{~Pb}(\mu)$ выражается с течением времени в накоплении ураногенных изотопов ${ }^{206} \mathrm{~Pb}$ и ${ }^{207} \mathrm{~Pb}$, дающих на диаграмме изотопных отношений $\mathrm{Pb}$ изохронный строй точек.

B Sm-Nd, Lu-Hf, Rb-Sr радиоизотопных системах при построении изохрон используются отношения радионуклидов и химических элементов. Концентрации последних из них зависят от степени частичного плавления в источнике, поэтому для построения вторичной изохроны материала источника должна вводиться поправка с коэффициентами распределения минерал-расплав, что вносит неопределенность в результаты возрастных оценок.

\section{1. ПРЕДШЕСТВУЮЩИЕ Pb-ИЗОТОПНЫЕ ОЦЕНКИ}

В начале 1990-х годов $\mathrm{Pb}$-изотопные данные по вулканическим породам полей Чангбайшан (Чангбай), Ханнуба, Минси, Датун, Куандян и Удаляньчи аппроксимировались трендом NHRL (Northern Hemisphere Reference Line, опорная линия Северного полушария) с наклоном, соответствующим возрасту 1.77 млрд лет [Basu et al., 1991]. Позже по Pbизотопным данным вулканических пород и их глубинных включений на полях Куандян и Ханнуоба были обозначены эпизоды метасоматического обогащения континентальной литосферы около 3.38 и 2.65 млрд лет назад [Tatsumoto et al., 1992]. Тогда же был определен интервал изотопных отношений $\mathrm{Pb}$ в миоценовых базальтах Линьдзю (п-ов Шаньдун), перекрывший весь спектр отношений вулканических пород Восточного Китая при распределении фигуративных точек вдоль линии с наклоном, соответствующим возрасту около 2.57 млрд лет. Эти точки относились к вторичной изохроне плавившегося материала раннедокембрийского литосферного мантийного киля [Zartman et al., 1991]. Продемонстрирован также особый подход к анализу изотопных отношений $\mathrm{Pb}$ вулканических пород вулканов Лаохейшан и Хуошаошан поля Удаляньчи [Kuritani et al., 2013]. Исходя из предположения о происхождении калиевых магматических расплавов из слэба, стагнирующего в переходном слое мантии, их источнику был присвоен возраст 1.5 млрд лет по модифицированной модели рудных свинцов [Stacey, Kramers, 1975].

Данные по изотопным отношениям ураногенного $\mathrm{Pb}$ верхнемеловых - палеогеновых вулканиче- 
ских пород Гоби и позднекайнозойских вулканических пород северной и западной части Удоканского поля аппроксимировались линией с наклоном вторичной изохроны около 4.35 млрд лет, а позднекайнозойских вулканических пород Хангая линией с наклоном вторичной изохроны около 0.66 млрд лет [Rasskazov, Chuvashova, 2018]. Геохимические исследования пород поля Удаляньчи выявили латеральную гетерогенность источников с $\mathrm{Pb}-\mathrm{Pb}$ оценками возраста материала, вовлеченного в плавление под разными вулканами от 1.88 млрд лет до современных [Rasskazov et al., 2019].

\section{2. ПОСТАНОВКА ЗАДАЧИ ИССЛЕДОВАНИЯ}

Получение для источников $\mathrm{Pb}$-изотопной метки 4.35 млрд лет предполагает вовлечение в плавление материала ранней Земли. С точки зрения эволюции $\mathrm{Pb}$ от его первородного состава разрабатывалась изотопная систематика отторженного (рудного) $\mathrm{Pb}$. В гнейсах Амитсок (пояс Исуа, юг Западной Гренландии) свинец, близкий к «согласному», был аппроксимирован в работе [Stacey, Kramers, 1975] кривой с $\mu=(238 \mathrm{U} / 204 \mathrm{~Pb})=9.7$, исходящей из точки 3.7 млрд лет. Предполагалось, что этот момент соответствовал пику корообразующего события. Предшествовавшие процессы описывались кривой накопления радиогенных свинцов при $\mu=7.2$ (ниже значения «согласного» свинца). Рудный свинец был аномальным, т.е. часть фигуративных точек изотопных отношений Рb смещалась правее геохроны - параметрической прямой с наклоном, соответствующим возрасту Земли. Долгое время модель применялась на практике для ориентировочных оценок времени отторжения свинца на рудных месторождениях. Смена $\mu$, отразившаяся в эволюции $\mathrm{Pb}$ ранней Земли, связывалась с потерей летучего $\mathrm{Pb}$ (относительно тугоплавкого U) при метеоритных бомбардировках, подобно потере Протоземлей других летучих элементов, таких как $\mathrm{Zn}, \mathrm{He}, \mathrm{Ne}$ и др. [Albarède, 2009; Albarède et al., 2013; Tucker, Mukhopadhyay, 2014; Dhaliwal et al., 2018]. Допускалось также сильное влияние на содержание в мантии умеренно летучего $\mathrm{Pb}$ только сегрегации сульфидов в ядро и лишь незначительно - влияние добавки позднего шпона [Wood et al., 2010].

В отличие от модели Дж.С. Стэйси, Дж.Д. Крамерса и подобных моделей рудного $\mathrm{Pb}$, основанных на допущениях временной смены значений $\mu$ (см. обзор в работе [Dickin, 2018]), в сопряженной модели конкордии-дискордии и диффузионной дискордии [Rasskazov et al., 2010] предварительно выбранные рубежи не обозначались. Эволюция изотопов $\mathrm{Pb}$ рассчитывалась для совокупности фигуративных точек при постоянном значении $\mu$. Значение этого показателя - результат аппроксимации точек линией диффузионной дискордии. В соответствии с гипотезой о «горячей» Земле, в сопряженных расчетах объединялись модели: 1) Холмса-Хаутерманса, характеризующая накопление радиогенного рудного $\mathrm{Pb}$ и 2) Вассербурга, воспроизводящая эволюцию $\mathrm{Pb}$ по диффузионной дискордии. В совместных расчетах по двум моделям определялось два момента времени: 1) момент $T$ перехода от расплавленного состояния к кристаллическому с замыканием U-Pb-изотопной системы и 2) момент $t$ отторжения $\mathrm{Pb}$ в рудный минерал. Радиогенный $\mathrm{Pb}$ накапливался в расплавленной Земле при смещении от геохроны вдоль конкордии, а при фиксации внешней вязкой оболочки эволюционировал по диффузионной дискордии. В рамках сопряженной модели на юге Сибири были определены разные сценарии образования рудного $\mathrm{Pb}$ в раннедокембрийской коре Гарганского блока и южного края Сибирской платформы. В первой структуре отторгался свинец В-типа из системы со значением $T=4.31$ млрд лет назад во временном интервале $t=2.3-1.4$ млрд лет назад, во второй - свинец J-типа из системы со значением $T=3.82$ млрд лет назад в интервале $t=1.80-0.25$ млрд лет назад. Значения $\mu$ составляли соответственно 11.0 и 20.1.

Из полученных возрастных интерпретаций $\mathrm{Pb}-$ $\mathrm{Pb}$-изотопных отношений в U-содержащих источниках вулканических пород и в безурановых свинецсодержащих минералах рудных месторождений следует необходимость построения генеральной систематики источников с учетом полного плавления ранней Земли. Модели глобальной сейсмической томографии [Gu et al., 2001; и др.] обнаруживают существенный контраст скоростей наиболее верхней (до 660 км) и нижней (1800-2900 км) части мантии современной Земли при малом контрасте скоростей на промежуточных глубинах мезосферы (660-1800 км). С глубины 670 км вязкость резко растет, достигая максимума на отметке около 1000 км [Rudolph et al., 2015]. В моделях эволюции Земли допускается возрастание вязкости мантии сверху вниз почти на два порядка [Bunge et al., 1996]. Нижняя мантия рассматривается как часть основной конвектирующей системы, но ее высокая вязкость может фактически привести к длительной изоляции больших нижнемантийных ядерсгустков от быстро конвектирующей верхней мантии [Becker et al., 1999]. Глобальная эволюция Земли объясняется в рамках гипотезы двуслойной мантийной конвекции, предполагающей конвективную нестабильность верхней мантии и сохранность в нижней мантии материала валовой силикатной Земли (Bulk Silicate Earth). По гипотезе [Allègre, 1997, 2002], число Рэлея во времени менялось с переходом от докембрийской конвекции, не 


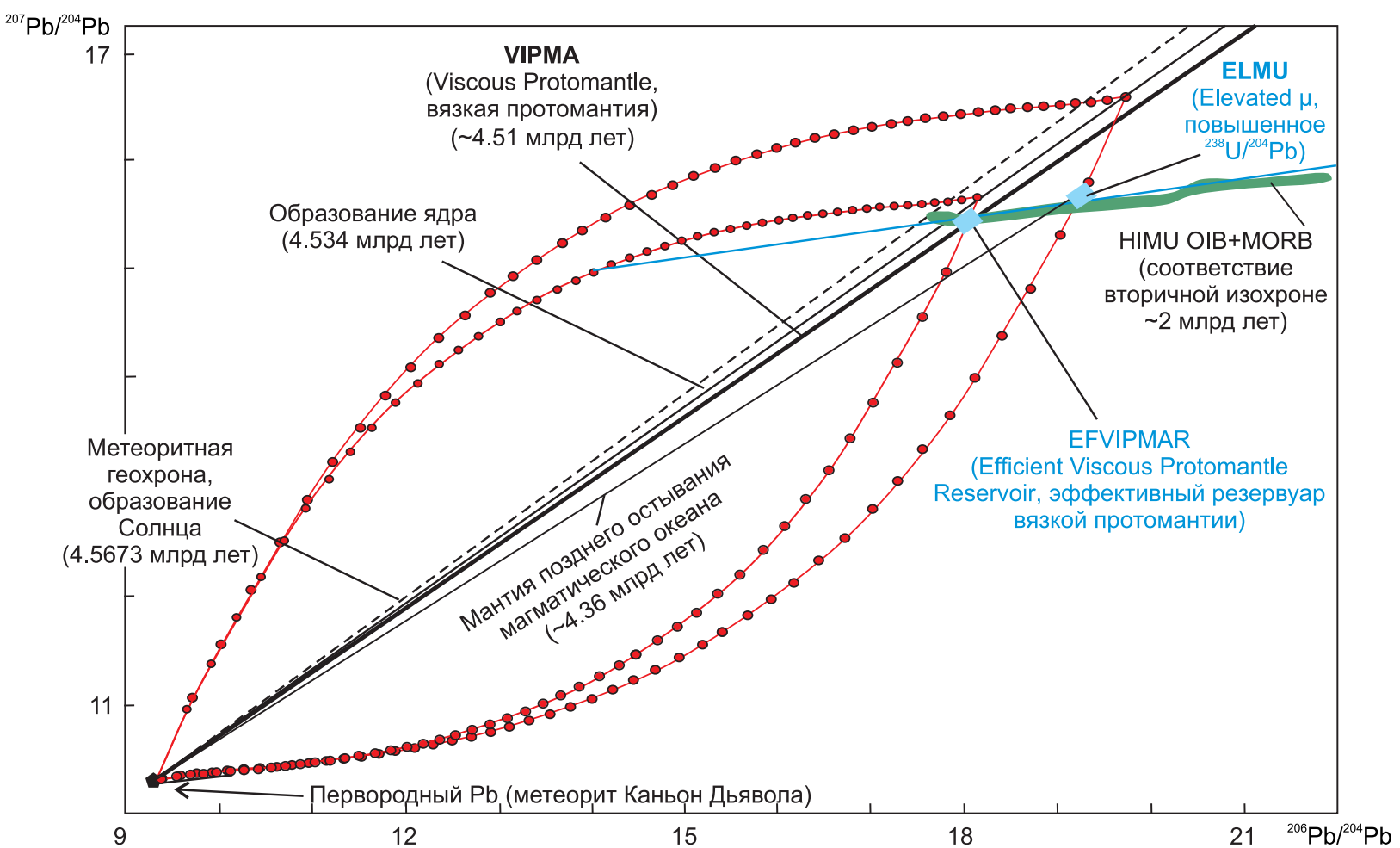

Pис. 1. Схематичная диаграмма эволюции ураногенного Pb. Показаны метеоритная геохрона [Connelly et al., 2012], линия образования ядра и тренд HIMUOIB+MORB [Hart, Gaetani, 2006], линии вязкой протомантии и мантии позднего остывания магматического океана, выразившиеся, соответственно, в компонентах EFVIPMAR и ELMU (настоящая работа). Все первичные изохронные линии центрированы на изотопных отношениях первородного свинца троилита из метеорита Каньон Дьявола (Nanton): ${ }^{207} \mathrm{~Pb} /{ }^{204} \mathrm{~Pb}=10.307094,{ }^{206} \mathrm{~Pb} /{ }^{204} \mathrm{~Pb}=9.305875$ [Blichert-Toft et al, 2010]. Pb-изотопные оценки возраста первичного ELMU в источниках вулканических пород древнее оценок, вытекающих из теоретической модели сульфидного секвестра $\mathrm{Pb}$ из мантии при образовании ядра [Hart, Gaetani, 2006]. Лучшее приближение дает модель эволюции $\mathrm{Pb}$ от геохроны (модель не показана).

Fig. 1. Schematic diagram of uranogenic Pb evolution. The meteorite geohron [Connelly et al., 2012], the core formation line, the HIMU OIB + MORB trend [Hart, Gaetani, 2006], and the lines of viscous protomantle and lately cooling magmatic ocean, expressed in the EFVIPMAR and ELMU components, respectively (this work), are shown. All primary isochron lines are focused on the primordial lead isotope ratios of troilite from the Canyon Diablo meteorite (Nanton): ${ }^{207} \mathrm{~Pb} / 204 \mathrm{~Pb}=10.307094$, ${ }^{206} \mathrm{~Pb} /{ }^{204} \mathrm{~Pb}=9.305875$ [Blichert-Toft et al., 2010]. The $\mathrm{Pb}$-isotope estimates of the primary ELMU age of volcanic rock sources are older than those from the theoretical model of the sulfide sequester of $\mathrm{Pb}$ from the mantle during the core formation [Hart, Gaetani, 2006]. A better approximation is provided by the Pb evolution model from the geochron (this model is not shown here).

сопровождавшейся субдукцией слэбов в нижнюю мантию, к современной глобальной структуре Земли, характеризующейся проникновением океанических плит в нижнюю мантию.

В модели Земли переменной вязкости, как основы генеральной систематики источников континентальных вулканических пород, предполагается проявление в их компонентном составе, прежде всего, валового состава протомантии, образовавшейся при остывании магматического планетарного океана. На диаграмме изотопных отношений ураногенного $\mathrm{Pb}$ (рис. 1) наклон траектории протомантии определяется временем ее перехода от конвектирующей системы магматического океана расплавленной Земли в вязкое сос- тояние. Траектория вязкой протомантии (Viscous Protomantle, или VIPMA), начинающаяся от первородного свинца метеорита Каньон Дьявола, проходит правее геохроны. Материал, соответствующий VIPMA, перерабатывался в геологической истории Земли в самой верхней (менее 660 км) и нижней (1800-2900 км) части мантии и мог сохраниться до настоящего времени в глобальном резервуаре мезосферы глубинного интервала 660-1800 км и в виде фрагментов протолитосферы малых глубин в древнейших докембрийских блоках ранней консолидации вязкой протомантии. Резервуар вязкой протомантии эффективно пополнял верхние слои мантии, испытавшие дифференциацию в истории Земли. 


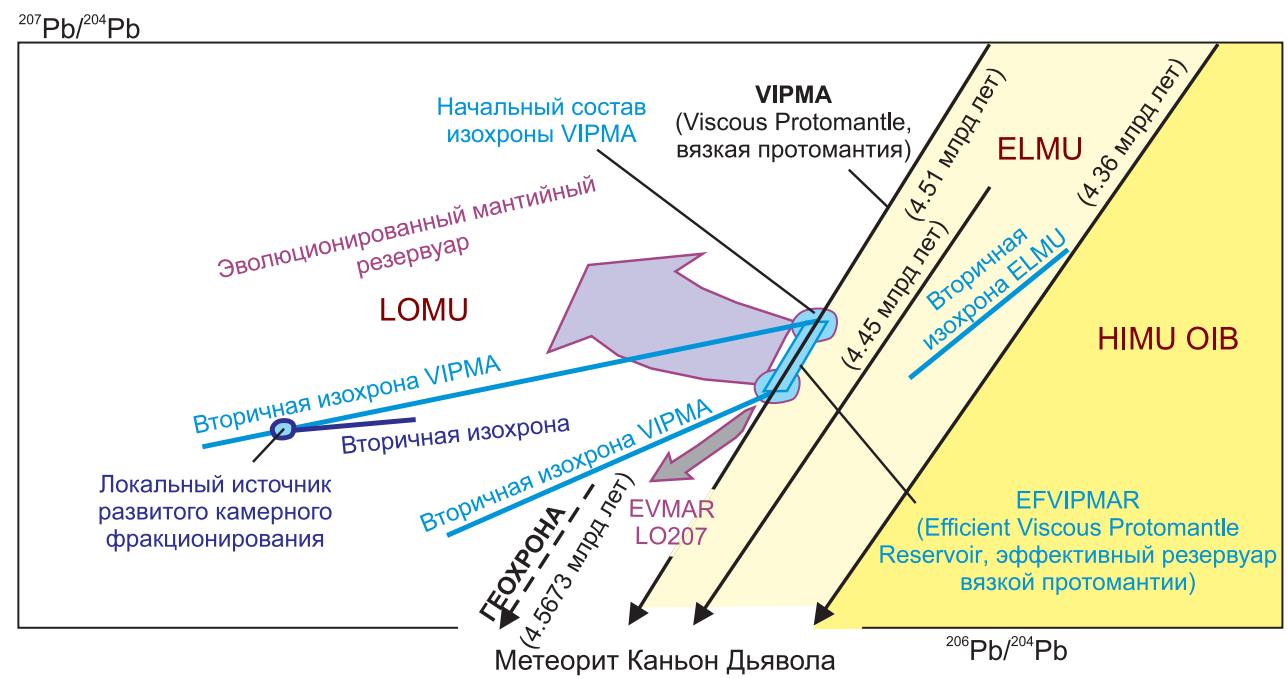

Рис. 2. Основные характеристики мантийных источников вулканических пород Азии на условной диаграмме изотопных отношений ураногенного Pb. Различаются области низкого $\mu$ (LOMU), повышенного $\mu$ (ELMU) и высокого $\mu$ (HIMU).

Fig. 2. The main signatures of mantle sources for volcanic rocks from Asia on a plot of the conventional uranogenic isotope $\mathrm{Pb}$ ratios. Low $\mu$ (LOMU), elevated $\mu$ (ELMU), and high $\mu$ (HIMU) compositions are discriminated.

Переработка материала вязкой протомантии на глубине менее 660 км сочеталась с эпизодическим поступлением протомантийных порций из нижней мантии в верхнюю, что отражалось в разновозрастных вторичных изохронах (отходящих от

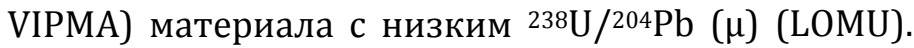
По начальным точкам таких вторичных изохрон ограничивается отрезок прямой, соответствующий эффективному резервуару вязкой протомантии (Efficient Viscous Protomantle Reservoir, EFVIPMAR). Часть фигуративных полей пород, заметно оторванная от траектории VIPMA, рассматривается как тренд эволюционированных мантийных резервуаров (Evolved Mantle Reservoirs, EVMAR). Ocoбый тренд проявлен в снижении $206 \mathrm{~Pb} / 204 \mathrm{~Pb}$ относительно VIPMA. Смещение точек обозначено эволюционированным трендом Low 207Pb (LO207) (рис. 2).

Остывание магматического океана Земли, сопровождавшееся возрастанием вязкости протомантии, запаздывало в глубинной части мезосферы, что выражалось в уменьшении наклона линии резервуара вязкого мантийного материала. В результате образовался материал с повышенным

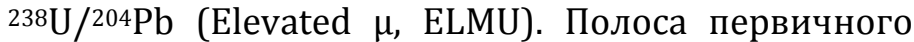
ELMU имеет наклон, соответствующий возрастному интервалу 4.45-4.36 млрд лет. Резервуар ELMU обособлен от резервуара LOMU.

В отличие от источников вулканических пород резервуара ELMU, источники HIMU OIB обозначают резко выраженный тренд повышения ${ }^{238 \mathrm{U} / 204 \mathrm{~Pb}}$ около 2 млрд лет назад [Hart, Gaetani, 2006]. Нали- чие тренда HIMU свидетельствует об акте секвестpa $\mathrm{Pb}$ из нижней мезосферы в ядро. Если это так, то вулканические породы с характеристикой HIMU служат прямым показателем активности плюмового источника нижнего граничного слоя конвектирующей мантии. В Азии редкие составы HIMU идентифицированы только в Индии.

Отмечаются также случаи распределения фигуративных точек вулканических пород территорий в виде коротких вторичных изохрон локальных источников развитого камерного фракционирования.

По двустороннему утонению переходного слоя в моделях сейсмической томографии на территории Азии выделяются только три первичные расплавные аномалии: Гобийская, Западно-Забайкальская и Куньлуньская [Rasskazov, Chuvashova, 2018]. Вулканические породы распределены в подвижных системах Азии: Центрально-Азиатской и ОлекмаСтановой орогенных, Байкальской, Циркум-Ордосской и Восточно-Китайской рифтовых, а также в Индо-Азиатской зоне коллизии и на п-вах Индостан и Индокитай. Обратимся к определению материала VIPMA, LOMU и ELMU в источниках вулканических пород этих территорий (рис. 3).

\section{3. РЕЗЕРВУАР LOMU, ПРОИЗВОДНЫЙ VIPMA}

\subsection{1. Траектория VIPMA}

На диаграмме изотопных отношений ураногенного $\mathrm{Pb}$ (рис. 4) совокупность фигуративных точек 

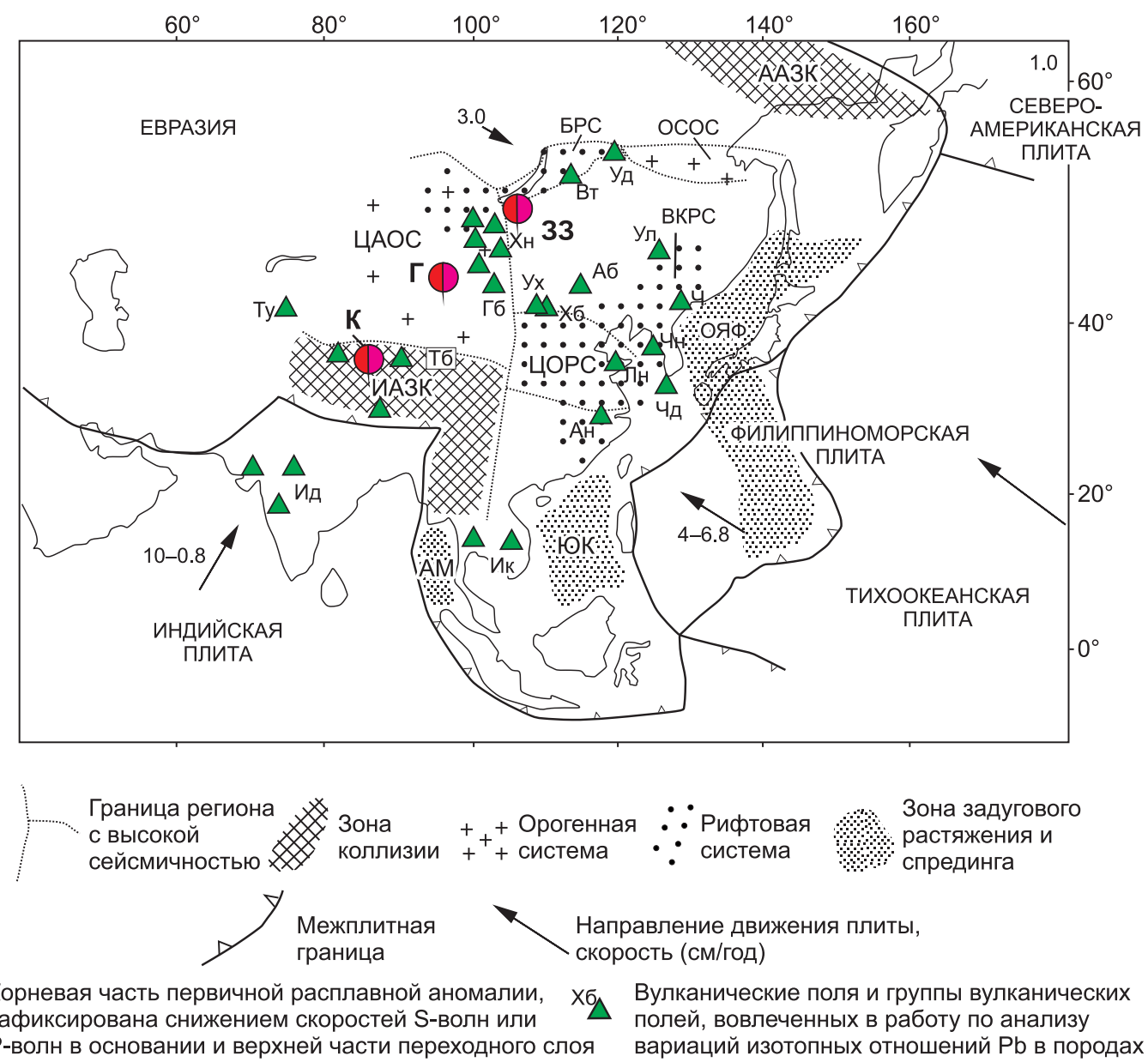

Рис. 3. Кайнозойские подвижные системы Азии, распределение первичных расплавных аномалий по моделям сейсмической томографии и расположение вулканических территорий, вовлеченных в работу по анализу вариаций изотопных отношений $\mathrm{Pb}$.

Коллизионные зоны: ИАЗК - Индо-Азиатская, ААЗК - Американско-Азиатская. Орогенные системы: ЦАОС - Центрально-Азиатская, ОСОС - Олекмо-Становая. Рифтовые системы: БРС - Байкальская, ЦОРС - Циркум-Ордосская (Шаньси), ВКРС - ВосточноКитайская. Глубоководные впадины, задуговый рифтогенез и спрединг: ОЯФ - Охотско-Японско-Филиппинская, ЮК - ЮжноКитайская, АМ - Андаманского моря. Корневые части первичных расплавных аномалий переходного слоя: Г - Гобийская, 33 Западно-Забайкальская, K - Куньлуньская [Chuvashova et al., 2017a]. Вулканические территории: Ч - Чангбай, Чд - Чеджу, Чн Чеунгок, Ул - Удаляньчи, Аб - Абага-Даленуор, Лн - Линьдзю, Ан - Анхой, Хб - Ханнуоба, Ух - Уланхада, Гб - Гоби, Хн - Хангай, Вт - Витим, Уд - Удокан, Ту - Туюн, Тб - Тибет, Ид - Индостан, Ик - Индокитай.

Fig. 3. Cenozoic mobile systems in Asia, distribution of primary melting anomalies from seismic tomography models, and locations of volcanic areas involved in analyzing the variations of $\mathrm{Pb}$ isotope ratios.

Collision zones: ИАЗК - Indo-Asian, ААЗК- American-Asian. Orogenic systems: ЦАОС - Central Asian, OCOC - Olekma-Stanovoy. Rift systems: БРС - Baikal, ЦОРС - Circum-Ordoss (Shanxi), ВКРС - East China. Deep-water basins, back-arc rifting and spreading: ОЯФ - Okhotsk-Japan-Philippine, ЮК - South China, AM - Andaman Sea. The root parts of the primary (transition layer) melting anomalies: Г- Gobi, 33- West Transbaikal, K - Kunlun [Chuvashova et al., 2017a]. Volcanic areas: Ч - Changbai, Чд - Jeju, Чн - Cheungok, Ул - Udalyanchi, Аб - Abaga-Dalenyuor, Лн - Linju, Ан - Anhui,Хб - Hannuoba, Ух - Wulanhada, Гб - Gobi, Хн - Наngay, Вт - Vitim, Уд Udokan, Ту - Tuyun, Тб - Tibet, Ид - Hindustan, Ик - Indochina.

пород Гобийской группы вулканических полей аппроксимируется линией с наклоном, соответствующим возрасту около 4.35 млрд лет. Тренд пород северо-запада Удоканского поля слегка отклоняется от тренда гобийских пород с относительным увеличением крутизны наклона. Этот тренд аппроксимируется линией с наклоном, соответствующим возрасту около 4.51 млрд лет.
В отличие от линии пород Гобийской группы полей, линия пород северо-запада Удоканского поля попадает на фигуративную точку первородного свинца метеорита Каньон Дьявола. Такое соответствие служит основанием для обозначения линии пород северо-запада Удоканского поля в качестве ориентировочной траектории VIPMA. Она протягивается от фигуративной точки первородного 


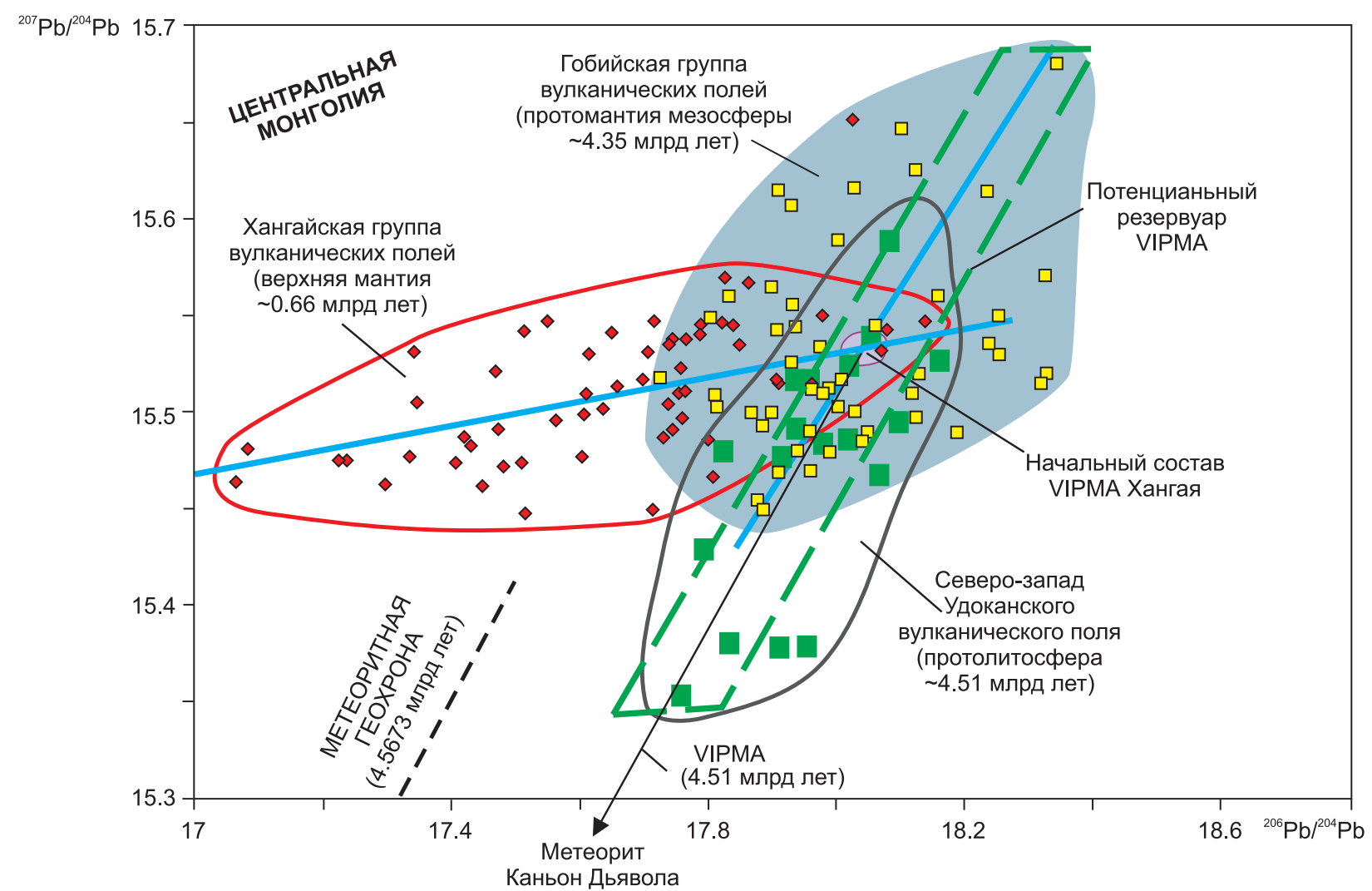

Рис. 4. Изотопные отношения ураногенного $\mathrm{Pb}$ в породах Центральной Монголии и Северо-Западного Забайкалья. Показаны данные по породам первичной Гобийской и вторичной Хангайской расплавных аномалий Центральной Монголии в сопоставлении с данными по породам вторичной Удоканской расплавной аномалии (северо-запад Удоканского поля) [Rasskazov, Chuvashova, 2018]. Эмпирическая траектория VIPМА с наклоном, соответствующим возрасту около 4.51 млрд лет, смещена правее параметрической линии (геохроны), наклон которой соответствует возрасту наиболее высокотемпературного метеоритного материала Солнечной системы 4.5673 млрд лет [Connelly et al., 2012]. По линии изотопных отношений ураногенного Рb пород Хангайской группы полей определяется верхнее ограничение EFVIPMAR со значением ${ }^{206} \mathrm{~Pb} /{ }^{204} \mathrm{~Pb}=18.04$.

Fig. 4. Uranogenic $\mathrm{Pb}$ isotope ratios of rocks from Central Mongolia and North-Western Transbaikalia. The data on rocks from the primary Gobi and secondary Hangaymelting anomalies of Central Mongolia are shown in comparison with the data on rocks from the secondary Udokanmelting anomaly (north-west of the Udokan field) [Rasskazov, Chuvashova, 2018]. The empirical VIPMA locus with a slope corresponding to an age of about 4.51 Gyr is shifted to the right of the parametric line (geochron), the slope of which corresponds to the age of the high-temperature meteoritic material of the Solar System, 4.5673 Gyr [Connelly et al., 2012]. From the line of uranogenic Pb isotopic ratios of the Hangay group of fields, the upper limit of the EFVIPMAR ${ }^{206} \mathrm{~Pb} /{ }^{204} \mathrm{~Pb}=18.04$ is determined.

свинца до схождения линии, аппроксимирующей данные по породам Гобийской группы полей и северо-запада Удоканского поля, и линии, аппроксимирующей данные по породам Хангайской группы полей. Потенциальный резервуар VIPMA охватывает интервал значений $206 \mathrm{~Pb} / 204 \mathrm{~Pb}$ гобийских и удоканских вулканических пород от 17.7 до 18.3.

\subsection{2. Вторичные изохроны VIPMA}

Этот тип источников представлен трендами вулканических пород Хангайской группы полей и полей Чангбай (частично), Линьдзю, Ханнуоба. Верхнее положение занимает тренд вулканических пород Хангайской группы полей, нижнее - поля Линьдзю, промежуточное положение - тренды вулканических пород полей Чангбай и Ханнуоба.

Породы Хангайской группы полей датированы в возрастном диапазоне последних 17 млн лет. Фигуративные точки этих пород обнаруживают непрерывный ряд от отношения ${ }^{206} \mathrm{~Pb} /{ }^{204} \mathrm{~Pb} 18.04$ на траектории протомантии до его значения 17.06, обусловленного низким $238 \mathrm{U} / 204 \mathrm{~Pb}$ отношением в источнике. Аппроксимирующая линия имеет наклон, соответствующий возрасту около 660 млн лет. На продолжении тренда пород Хангайской группы полей, в области повышенных значений ${ }^{206} \mathrm{~Pb} /{ }^{204} \mathrm{~Pb}$, т.е. ELMU (см. рис. 2), находятся вулка- 

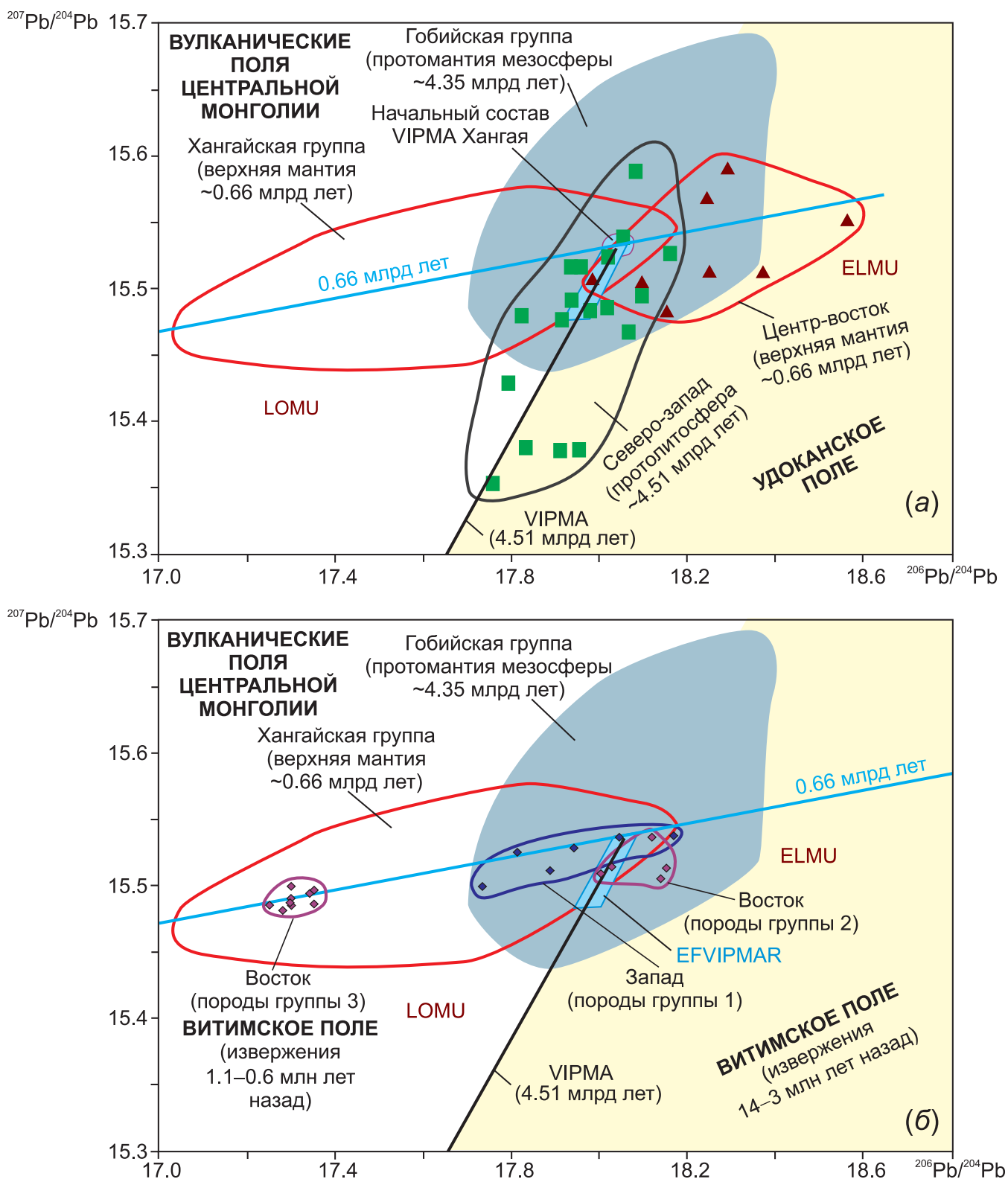

Рис. 5. Изотопные отношения ураногенного Рb в породах Центральной Монголии и Северо-Западного Забайкалья. Фигуративные поля пород первичной Гобийской и вторичной Хангайской расплавных аномалий Центральной Монголии (см. рис. 3): (a)- в сопоставлении с фигуративными полями пород вторичной Удоканской расплавной аномалии (северо-запад и центр-восток Удоканского поля), (б) - в сопоставлении с породами вторичной Витимской расплавной аномалии (запад и восток Витимского поля).

Fig. 5. Uranogenic $\mathrm{Pb}$ isotope ratios of rocks from Central Mongolia and North-Western Transbaikalia. Diagram $a$ shows the data fields of rocks from the primary Gobi and secondary Hangay melting anomalies of Central Mongolia (see Fig. 3) in comparison with the data fields of rocks from the secondary Udokan melting anomaly (north-western and central-eastern parts of the Udokan field). Diagram $b$ shows comparison with rocks from the secondary Vitim melting anomaly (western and eastern parts of the Vitim field).

нические породы центра-востока Удоканского поля. Характер вариаций изотопных отношений ураногенного $\mathrm{Pb}$ гобийских и хангайских вулканических пород имеет зеркальное отображение в вариациях ураногенных изотопных отношений $\mathrm{Pb}$ северо-востока и центра-востока Удоканского поля (рис. 5, a).
На рис. 5, б, приведена диаграмма изотопных отношений ураногенного $\mathrm{Pb}$ для пород Витимского вулканического поля Западного Забайкалья с учетом его пространственного положения между Удоканским полем и полями Центральной Монголии. В отличие от вулканических пород групп полей Центральной Монголии и Удоканского поля, породы 


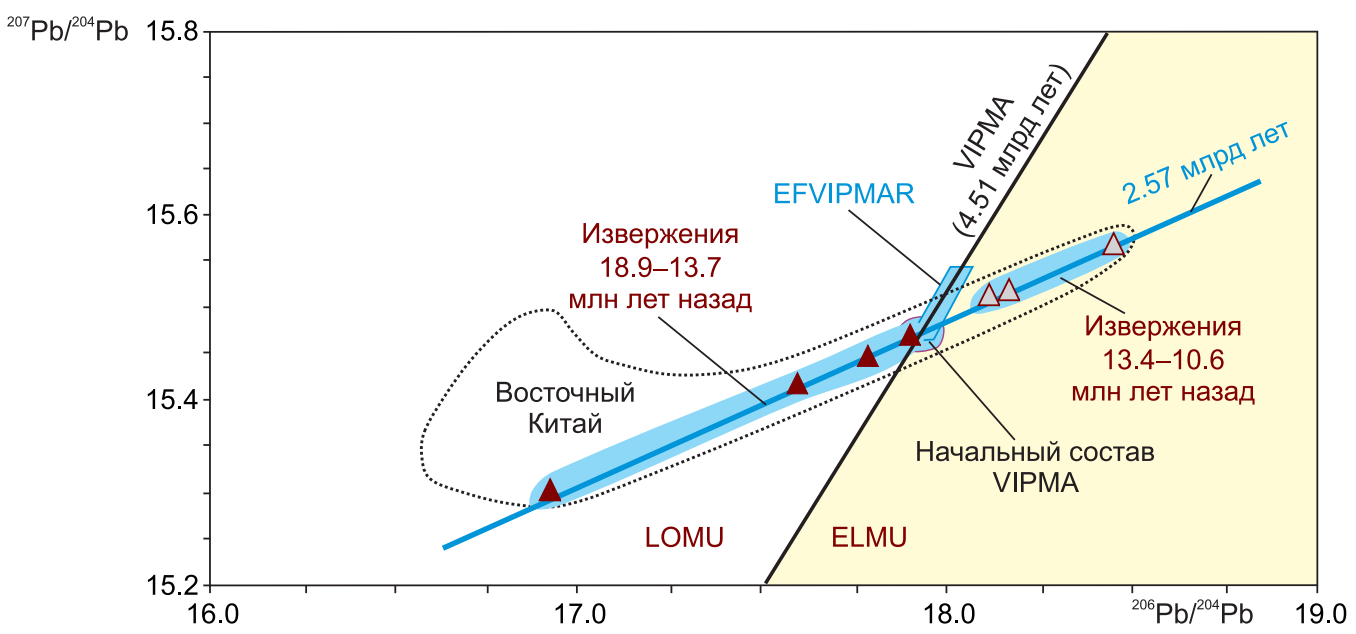

Рис. 6. Определение нижнего ограничения эффективного резервуара вязкой протомантии (EFVIPMAR)по изотопным отношениям ураногенного Рb пород поля Линьдзю (п-ов Шаньдун). Данные из работы [Zartman et al., 1991].

Fig. 6. Detection of the lower limit for the Effective Viscous Protomantle Reservoir (EFVIPMAR) by uranogenic Pb isotope ratios in rocks from the Linju field (Shandong Peninsula). Data from [Zartman et al., 1991].

Витимского поля обнаруживают слабую дисперсию точек. По времени и месту извержений на этом поле различаются три группы пород, две из которых (первая группа - запад, вторая группа - восток поля, возраст 14-3 млн лет) находятся вблизи траектории протомантии (в области EFVIPMAR), третья группа (восток поля, генерация извержений 1.1-0.6 млн лет назад) заметно смещена левее этой линии. Каждая группа пород характеризует отдельный источник.

Фигуративное поле пород первой группы смещено ниже линии 660 млн лет Хангайской группы полей и обозначает тренд с наклоном, в целом превышающим этот возраст. Расположение тренда вблизи протомантийной траектории свидетельствует о происхождении материала источника из древнейшего мантийного материала, активизированного до 660 млн лет назад. Источник характеризует породы запада Витимского поля, которые имеют общий компонент в изотопной систематике Nd [Rasskazov, Chuvashova, 2018].

Фигуративное поле пород второй группы, представляющей собой материал источника восточной части Витимского поля, - компактная совокупность точек, смещенных правее протомантийной траектории и ниже тренда пород группы 1. Такой состав интерпретируется как характеристика гомогенного источника ELMU (cм. рис. 2).

Компактная совокупность точек пород третьей группы, обособленная от точек двух других групп пород Витимского поля, существенно смещена левее траектории VIPMA и находится непосредственно на линии, аппроксимирующей фигуративное поле хангайских пород с наклоном, соответствую- щим возрасту 660 млн лет. Следовательно, можно предположить, что источник 3 представляет собой материал, претерпевший эволюцию и изотопную гомогенизацию одновременно с пароксизмом преобразования материала источников хангайских пород (т.е. около 660 млн лет назад). В отличие от хангайского мантийного материала, источник 3 витимских пород был конвективно гомогенизирован.

Породы поля Линьдзю (п-в Шаньдун, Китай) извергались в миоцене, во временном интервале 18.9-10.6 млн лет назад. По изотопным отношениям ураногенного $\mathrm{Pb}$ породы источника Линьдзю обозначают линию, наклон которой соответствует возрасту 2.57士0.17 млрд лет [Zartman et al., 1991]. Изохронные фигуративные точки лав, извергнутых 18.9-13.7 млн лет назад, распределяются левее траектории протомантии (относятся к LOMU), а фигуративные точки лав, извергнутых 13.4-10.6 млн лет назад, - правее ее (относятся к ELMU) (см. рис. 2). Отношение ${ }^{206} \mathrm{~Pb} /{ }^{204} \mathrm{~Pb}$ исходного состава вязкой протомантии источника Линьдзю - 17.96 (рис. 6).

Породы поля Ханнуоба в Северном Китае также имеют миоценовый возраст. В вулканических толщах перемежаются толеитовые базальты (tholeiitic basalts; TВ) и переходные, эволюционированные, примитивные базальты (transitional, evolved, primitive basalts; TEPB). Геохимические характеристики этих групп пород резко различны [Zhi et al., 1990]. Различие источников демонстрируется на диаграмме изотопных отношений ураногенного $\mathrm{Pb}$ (рис. 7). Фигуративные точки группы ТВ укладываются в тренд, наклон которого соответствует возрасту около 1.81 млрд лет. Тренд протягивается 


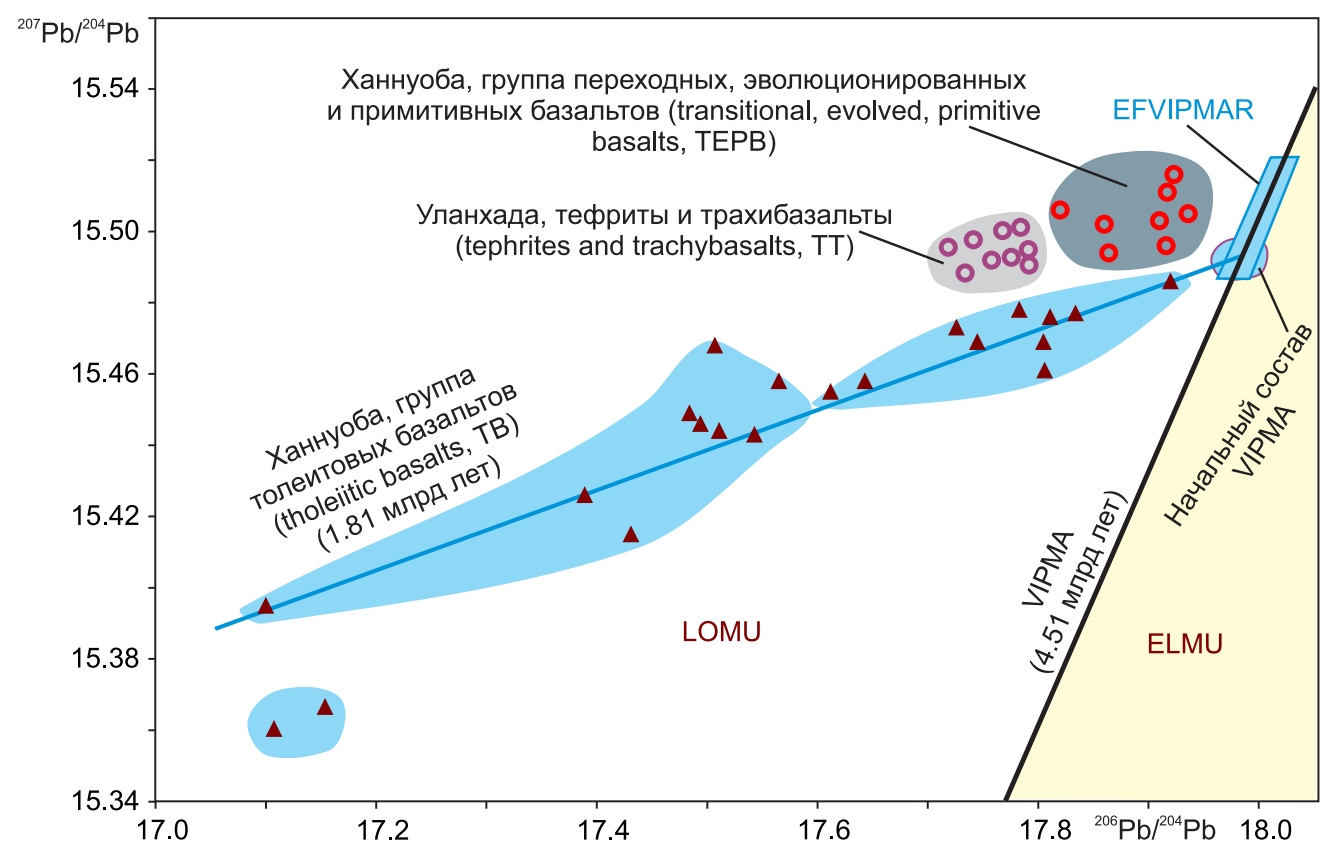

Рис. 7. Вариации изотопных отношений ураногенного Рb пород полей Ханнуоба и Уланхада относительно VIPMA. Данные из работ [Song et al., 1990; Fan et al., 2014].

Fig. 7. Variations of uranogenic Pb isotope ratios in rocks from the Hannuoba and Wulanhada fields relative to VIPMA. Data from [Song et al., 1990; Fan et al., 2014].

левее траектории протомантии при начальном значении ${ }^{206} \mathrm{~Pb} /{ }^{204} \mathrm{~Pb}=17.98$. Группа точек ТЕРВ поля Ханнуоба образует компактное изометричное поле вблизи траектории VIPMA выше тренда толеитовых базальтов. Подобно источнику ТВ, получившему развитие от траектории VIPMA, источник ТЕРВ мог быть производным вязкой протомантии, но с повышенным значением ${ }^{207} \mathrm{~Pb} / 204 \mathrm{~Pb}$ при ограниченном диапазоне ${ }^{206} \mathrm{~Pb} /{ }^{204} \mathrm{~Pb}$. Отсутствие линейности в совокупности ТЕРВ свидетельствует о происхождении материала из позднекайнозойского гомогенного источника конвектирующей мантии. По геохимическим параметрам источник ТЕРВ относится к бо́льшим глубинам, чем источник ТВ [Song et al., 1990; Zhi et al., 1990]. Порция глубинного материала под этим полем оставалась гомогенной и консервировалась, а порция, достигшая меньших глубин, дифференцировалась от фракций, соответ-

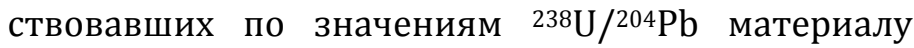
вязкой протомантии, до фракций с низкими значениями этого показателя. Тефриты и трахибазальты (TT) четвертичного поля Уланхада образуют изометричное поле точек в области LOMU рядом с полем ТЕРВ поля Ханнуоба и могут иметь сходное происхождение из конвектирующей мантии, хотя заметно смещены от траектории VIPMA. Не исключено, что источник ТТ образовался в результате преобразования источника ТЕРВ. Обоснование этого преобразования требует анализа дополнительных данных.
Вулканическое поле Чангбай сложено широким спектром пород основного состава (толеитовые базальты, калиевые трахибазальты, шошониты, щелочные базальты) и дифференциатов среднекислого состава (трахиты, щелочные трахиты, латиты, комендиты и пантеллериты). На диаграмме изотопных отношений ураногенного $\mathrm{Pb}$ породы основного состава разделились на четыре группы (рис. 8). В каждой группе имеются толеитовые базальты, калиевые трахибазальты и шошониты и только в группе 3 - щелочные базальты. Породы группы 1 относятся в основном к постщитовой стадии извержений 2.0-0.9 млн лет назад. В этой группе определены самые высокие отношения ${ }^{208} \mathrm{~Pb} /{ }^{204} \mathrm{~Pb}$. С траекторией вязкой протомантии соединена только группа 1 при значении ${ }^{206} \mathrm{~Pb} /{ }^{204} \mathrm{~Pb}=18.03$. Три другие группы смещены левее этой траектории с относительным возрастаниeм ${ }^{207} \mathrm{~Pb} /{ }^{204} \mathrm{~Pb}$.

\subsection{3. Эволюционированные составы VIPMA}

Резервуары этого типа представлены породами вулканических полей Чангбай (частично), Чеунгок и Удаляньчи. Эволюция и обособление резервуаров этих источников от материала протомантии сопровождались повторным вовлечением в переработку локальных общих компонентов, характеризующихся одинаковыми изотопными отношениями ураногенного $\mathrm{Pb}$. 


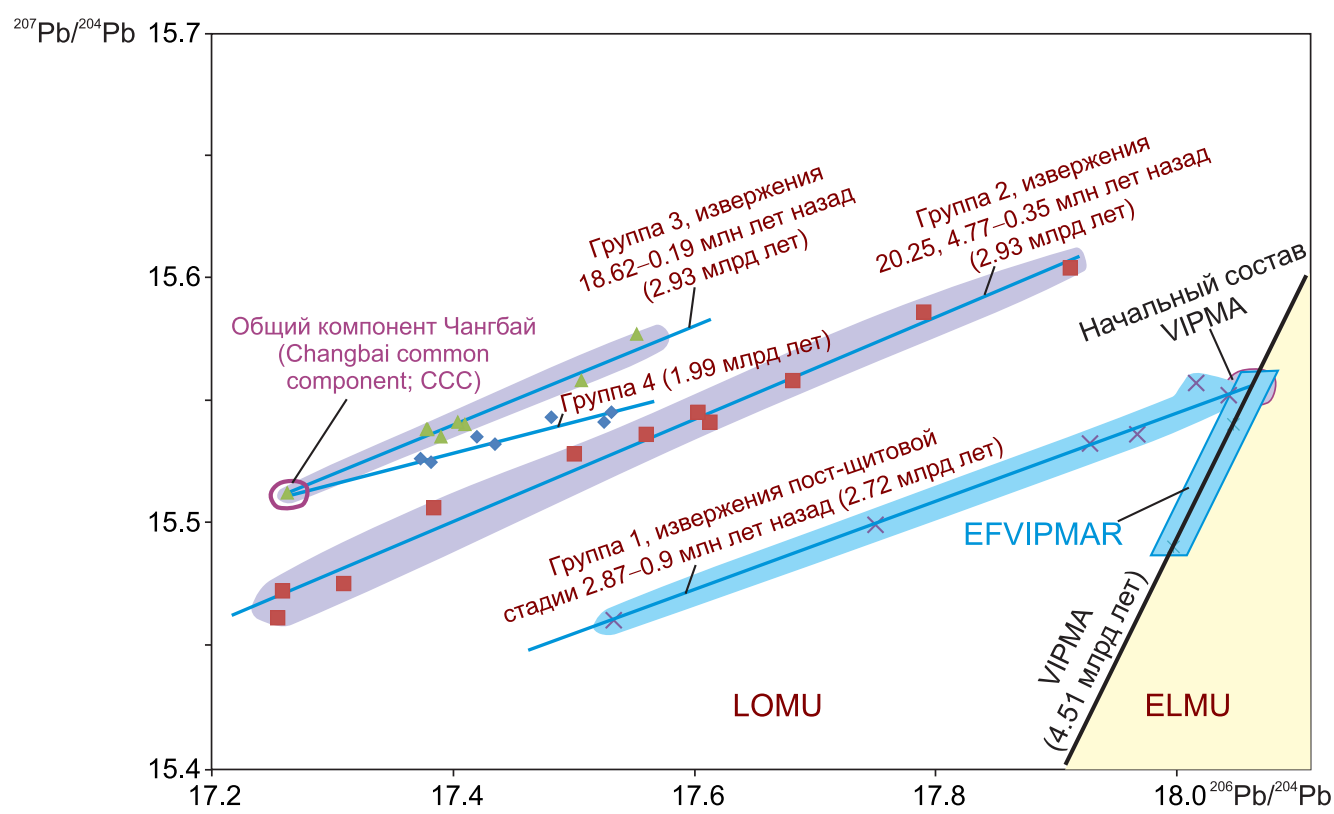

Рис. 8. Вариации изотопных отношений ураногенного Рb пород основного состава поля Чангбай относительно VIPMA. Группы пород с разными изотопными отношениями свинцов по содержаниям петрогенных оксидов не различаются между собой. Общий компонент Чангбай характеризуется наименее радиогенными изотопными отношениями $\mathrm{Pb}\left({ }^{206} \mathrm{~Pb} /{ }^{204} \mathrm{~Pb}=17.262,{ }^{207} \mathrm{~Pb} /{ }^{204} \mathrm{~Pb}=15.512\right.$, обр. GUO-11-04). Данные из работ [Basu et al., 1991; Wee, 1999; Zhang et al., 2018].

Fig. 8. Variations of uranogenic $\mathrm{Pb}$ isotope ratios in basic rocks from the Changbai field relative to VIPMA. The rock groups with different $\mathrm{Pb}$ isotope ratios do not differ in terms of major oxides. The Changbai common component shows the least radiogenic $\mathrm{Pb}$ isotope ratios $\left({ }^{206} \mathrm{~Pb} /{ }^{204} \mathrm{~Pb}=17.262,{ }^{207} \mathrm{~Pb} /{ }^{204} \mathrm{~Pb}=15.512\right.$, sample GUO-11-04). Data from [Basu et al., 1991; Wee, 1999; Zhang et al., 2018].

На вулканическом поле Чангбай породы представлены группами 2, 3 и 4. Для групп 2 и 3 получены одинаковые оценки возраста протолитов (около 2.93 млрд лет) (рис. 8). Эти группы эволюционировали от разного субстрата. Группа 3 смещена относительно группы 2 с повышением ${ }^{207} \mathrm{~Pb} /{ }^{204} \mathrm{~Pb}$. Группа 4 характеризуется наклоном аппроксимирующей линии, соответствующим возрасту 1.99 млрд лет. Общий компонент групп 3 и 4 (Changbai common component, CCC) отражает происхождение этих групп из единого гомогенного источника с наименее радиогенными изотопными отношениями $\mathrm{Pb}\left(206 \mathrm{~Pb} / 204 \mathrm{~Pb}=17.262,{ }^{207 \mathrm{~Pb}} /{ }^{204} \mathrm{~Pb}=15.512\right)$. Сначала, около 2.93 млрд лет назад, источник ССС дал эволюцию, реализовавшуюся в тренде точек группы 3, затем, около 1.99 млрд лет назад, - эволюцию, реализовавшуюся в тренде группы 4.

Другой характерный пример производных EVMAR - базальты вулканического поля Чеунгок. Оно находится на Корейском п-ове, в рифтовой долине Чугарйонг, заложенной на предполагаемой коллизионной границе между Северо-Китайским и Южно-Китайским блоками [Wee, 1999]. На диаграмме изотопных отношений ураногенного $\mathrm{Pb}$ фигуративные точки пород поля Чеунгок разделяются на два тренда: один - с наклоном, соответ- ствующим возрасту около 3.94 млрд лет, другой около 2.86 млрд лет. Тренды сходятся между собой при значениях ${ }^{206} \mathrm{~Pb} /{ }^{204} \mathrm{~Pb}=17.84,{ }^{207} \mathrm{~Pb} /{ }^{204} \mathrm{~Pb}=15.56$ (рис. 9). Эта область сходящихся трендов обозначает материал мантийного резервуара, образовавшегося около 3.94 млрд лет назад и вновь активизированного около 2.85 млрд лет назад.

Вулканическое поле Удаляньчи (Северо-Восточный Китай) сложено породами калиевой серии, характеризующейся высокими концентрациями несовместимых элементов. Концентрации $\mathrm{Pb}$ варьируются в диапазоне от 10 до 57 мкг/г. Ключевое значение имеет пространственно-временная смена продуктов извержений последних 2.5 млн лет [Rasskazov et al., 2016]. Активность вулканов этого поля была обусловлена плавлением материала не менее четырех источников, индивидуализированных в пространстве: Лаошантоу, Гелацю, Уоху и Молабу. Материал всех источников был производным общего резервуара (common reservoir, CR) $\left({ }^{206} \mathrm{~Pb} /{ }^{204} \mathrm{~Pb}=17.55,{ }^{207} \mathrm{~Pb} /{ }^{204} \mathrm{~Pb}=15.52\right)$, проявившегося в качестве общего компонента вулканических пород на разных территориях Восточной Азии [Rasskazov et al., 2014].

Извержения потока трахиандезитов Лаошантоу около 2.5 млн лет назад (источник Лаошантоу) и 


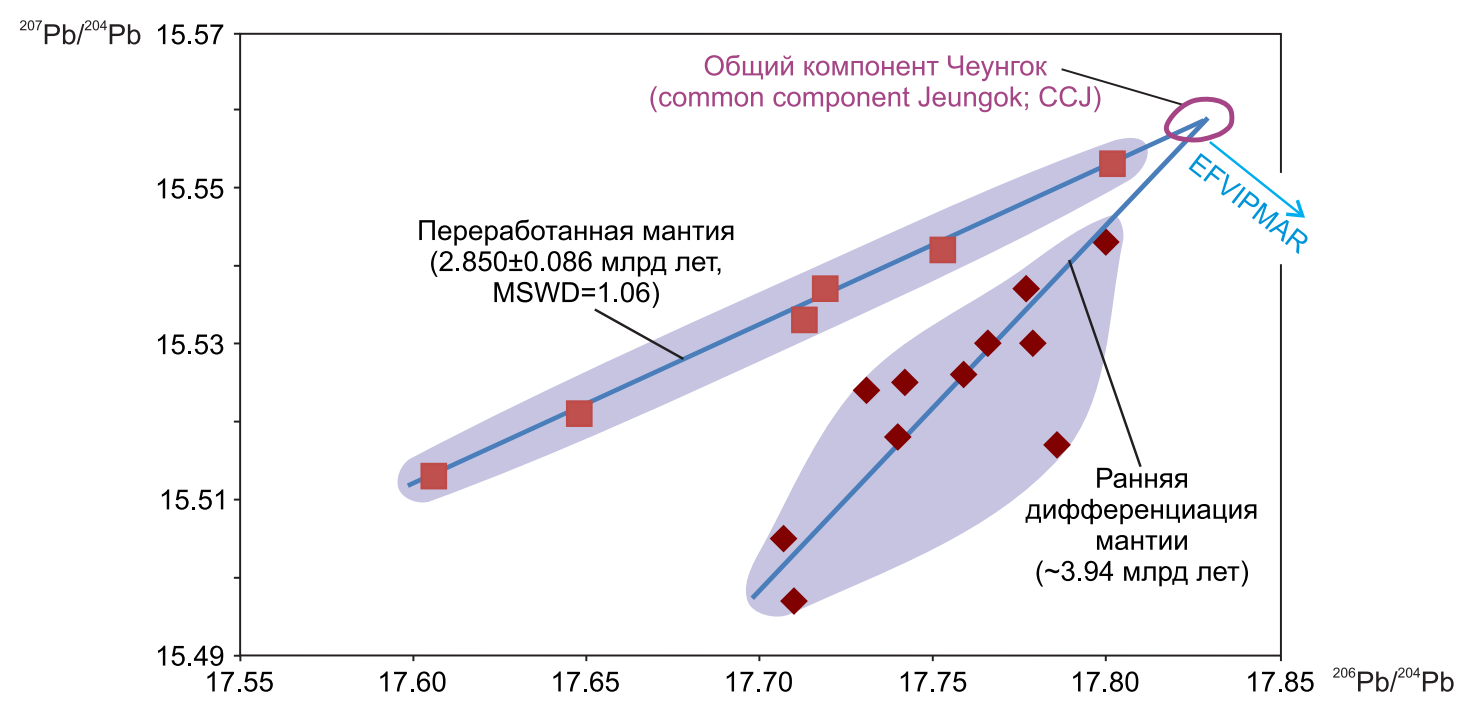

Рис. 9. Изотопные отношения ураногенного $\mathrm{Pb}$ в вулканических породах поля Чеунгок. Tраектория EFVIPMAR проходит за правой границей диаграммы. Данные [Wee, 1999; Choi et al., 2014; Sakuyama et al., 2014].

Fig. 9. Variations of uranogenic $\mathrm{Pb}$ isotope ratios in volcanic rocks from the Cheungok field. The EFVIPMAR locus passes beyond the right edge of the diagram. Data from [Wee, 1999; Choi et al., 2014; Sakuyama et al., 2014].

потока низко-Mg трахиандезибазальтов Древний Гелацюшан около 2.0 млн лет назад (источник Гелацю) были производными материала, отделившегося от общего резервуара. Для совокупности точек пород этих потоков получена вторичная изохрона $1.884 \pm 0.055$ млрд лет (MSWD=0.67). Начиная с 1.3 млн лет назад выплавки из источника Лаошантоу получили распространение только в небольшой доле смешанных составов с материалом источника Гелацю в низко-Mg породах вулканов Бидзиашан и Лаохейшан. Материал общего компонента источника Гелацю был представлен на вулкане Уохушан, извергавшемся 1.33-0.42 млн лет назад, в виде индивидуализированной короткой вторичной изохроны локального источника развитого камерного фракционирования (см. рис. 2). Фигуративные точки низко-Mg пород этого вулкана распределились вдоль линии диаграммы изотопных отношений ураногенного $\mathrm{Pb}$ с наклоном, соответствующим возрасту около 150 млн лет. Материал источника Гелацю частично переплавлялся под вулканом Уохушан до изотопной гомогенизации $\mathrm{Pb}$ с образованием вторичной изохроны на раннем этапе погружения бассейна Сунляо.

Источник Молабу характеризовался умеренно$\mathrm{Mg}$ составом расплавов, проявившихся в извержении материала, сформировавшего конус вулкана Молабушан в начале вулканического интервала последних 0.6 млн лет. В связи с отсутствием изохронного тренда точек для протолита источника Молабу его возраст не определяется. Материал протолита интерпретируется как конвектирующий. Источник Молабу недавно гомогенизировался и дал короткую вторичную изохрону камерного фракционирования. Умеренно- и низко-Мg продукты извержений вулканов Бидзиашан и Лаохейшан временного интервала последних 0.6 млн лет представлены смесью материала источников Молабу и Гелацю (рис. 10).

Роль локальных общих компонентов проявилась в распределении материала источников Лаошантоу, Гелацю и Молабу. Источника были индивидуализированы в локальные объемы развитого камерного фракционирования. Материал первого из них (Лаошантоу) распространился в ходе вулканических извержений на большинстве вулканов в смешении с материалом источников Гелацю и Молабу. Материал источника Молабу смешивался под вулканами с материалом источника Гелацю [Rasskazov et al., 2019].

Для вулканических пород провинции Анхой (Anhui) Восточного Китая обозначается эволюционированный резервуар VIPMA особого типа с низким ${ }^{207} \mathrm{~Pb} /{ }^{204} \mathrm{~Pb}$ (LO207). Вулканизм этой территории развивался в течение всего кайнозоя. Извержения проявились в зоне разлома Танлу, у северного края блока Янцзы. На диаграмме изотопных отношений ураногенного $\mathrm{Pb}$ фигуративное поле рассеянных фигуративных точек пород провинции Анхой распространяется левее и ниже EFVIPMAR (рис. 11).

Ключом к пониманию происхождения тренда EVMAR L0207 служат данные для пород четвертичного вулкана Нушан, которые по обедненным характеристикам $\mathrm{Nd}$ и $\mathrm{Sr}$ были отнесены к астеносферным выплавкам [Zou et al., 2000]. Между тем 

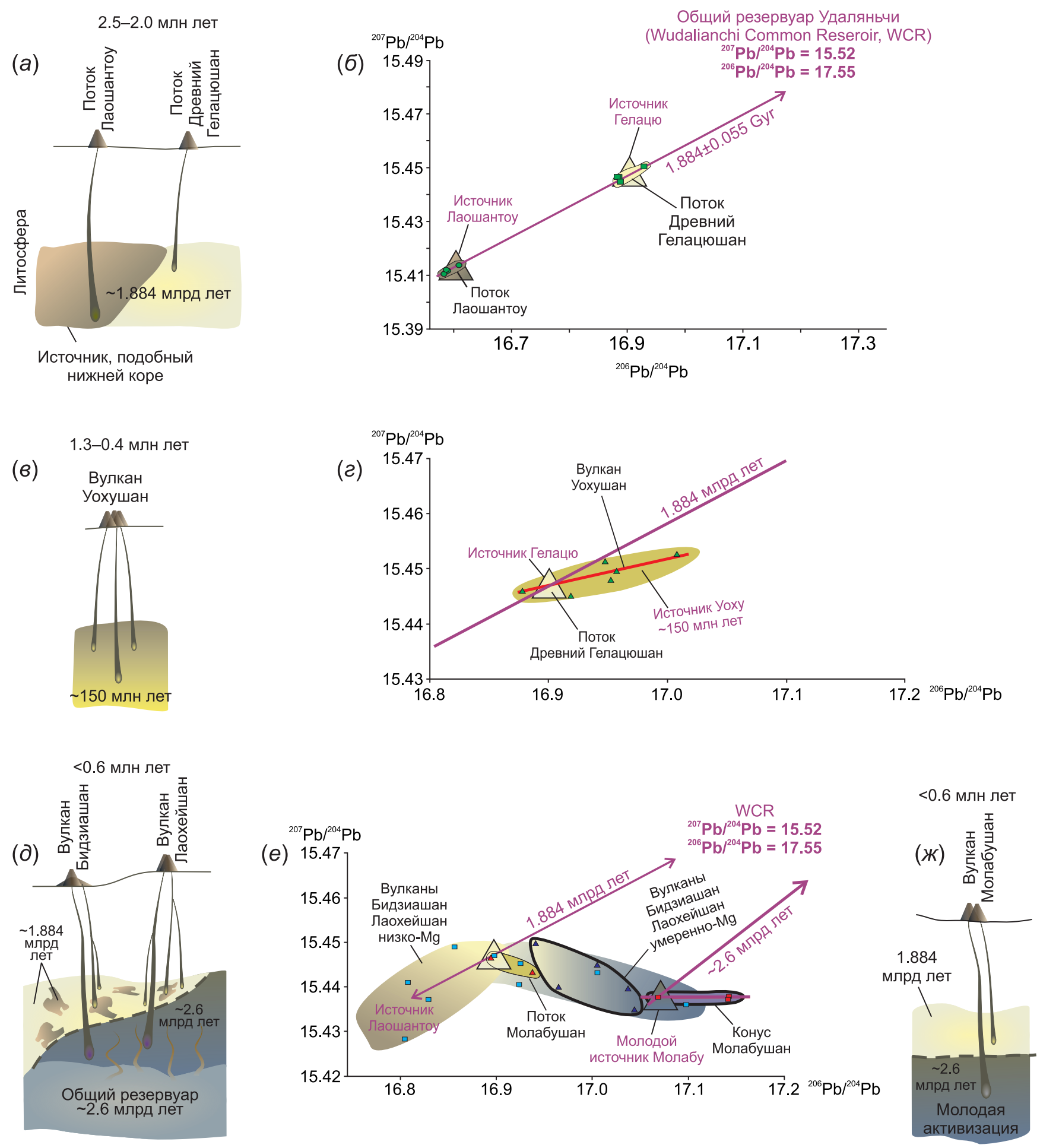

Рис. 10. Соотношение источников Лаошантоу, Гелацю, Уоху и Молабу поля Удаляньчи по изотопным отношениям ураногенного Pb в вулканических породах. Данные [Rasskazov et al., 2019] с изменениями.

Fig. 10. Relations between the Laoshantou, Gelaqiu, Wohu, and Molabu sources in the Wudalianchi field as inferred from uranogenic $\mathrm{Pb}$ isotope ratios in volcanic rocks. Modified after [Rasskazov et al., 2019].

породы этого вулкана на диаграмме изотопных отношений $\mathrm{Pb}$ не образуют изометричной совокупности, которая должна отражать конвективную гомогенизацию астеносферных расплавов. Отчетливый строй точек аппроксимируется линией с наклоном, который соответствует возрасту $3.744 \pm 0.290$ млрд лет (MSWD=2.9). Наличие тренда ранней дифференциации, направленного ниже EFVIPMAR, предполагает создание неоднородности, которая предопределила развитие тренда пород провинции 


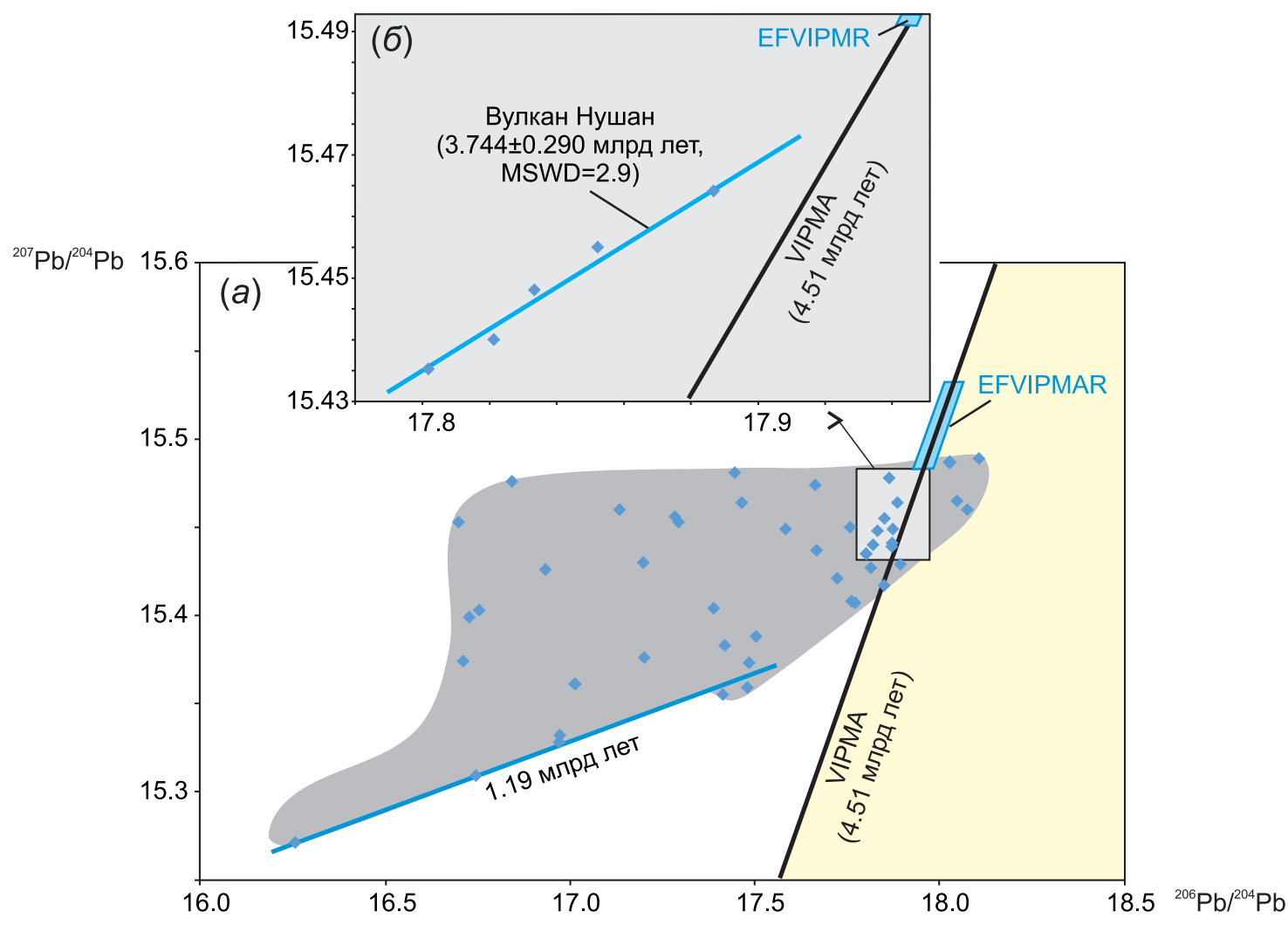

Рис. 11. Тренд LO207 вулканических пород провинции Анхой (Китай). Данные из работ [Zou et al., 2000; Xu, Zheng, 2017].

Fig. 11. The L0207 trend of volcanic rocks from the Anhui province (China). Data from [Zou et al., 2000; Xu, Zheng, 2017].

Анхой. Наклон строя точек в нижнем ограничении поля соответствует предельному возрасту эволюции 1.19 млрд лет.

\subsection{PE3EPBУAP ELMU}

\subsection{1. Полоса первичного ELMU}

Первичный резервуар ELMU представлен в расплавных аномалиях Чеджу, Куньлунь и АбагаДаленуор. Фигуративные поля пород этих расплавных аномалий заключены в полосе между линиями ELMUi (initial) и ELMUf (final) с наклонами по отношению к первородному Рb метеорита Каньон Дьявола, соответствующими возрасту 4.45 и 4.36 млрд лет (рис. 12).

Расплавная аномалия Куньлунь характеризуется ареалом вулканических пород возрастного интервала последних 18 млн лет, вытянутым на 1200 км в субширотном направлении, вдоль террейна Сонгпан-Ганзи. Вулканическому ареалу соответствует низкоскоростная аномалия, протягивающаяся в моделях сейсмической томографии, по крайней мере, на глубину 700 км. Следовательно, извергнутые магматические расплавы могли подниматься из нижней мантии.
На диаграмме изотопных отношений ураногенного $\mathrm{Pb}$ фигуративные точки вулканических пород территории возрастного интервала 8-3 млн лет распределились вдоль линии ELMUI. Наклон тренда свидетельствует об источнике ранней Земли. Фигуративное поле более молодых пород возрастом 2.8-0.2 млн лет частично перекрылось с полем пород возрастного интервала 8-3 млн лет и продвинулось в область более низких значений 207Pb/204Pb. Две фигуративные точки пород последних 0.5 млн лет попали в область перекрытия фигуративных полей возрастных интервалов 8-3 и 2.8-0.2 млн лет, а одна точка сместилась с относительным возрастанием обоих изотопных отношений ураногенного $\mathrm{Pb}$. Область перекрытия обозначила общий компонент расплавной аномалии Куньлунь (KLCC).

Поверхностное выражение расплавной аномалии Чеджу - вулканический о-в в южной части Японского моря, сложенный четвертичной серией щелочной базальт - гавайит - муджиерит, а также переходными и толеитовыми базальтами [Park et al., 2005]. Переходные базальты показали относительно низкие значения ${ }^{207} \mathrm{~Pb} /{ }^{204} \mathrm{~Pb}(15.592$ и 15.541) при повышенных значениях этого отношения в щелочных и толеитовых базальтах 


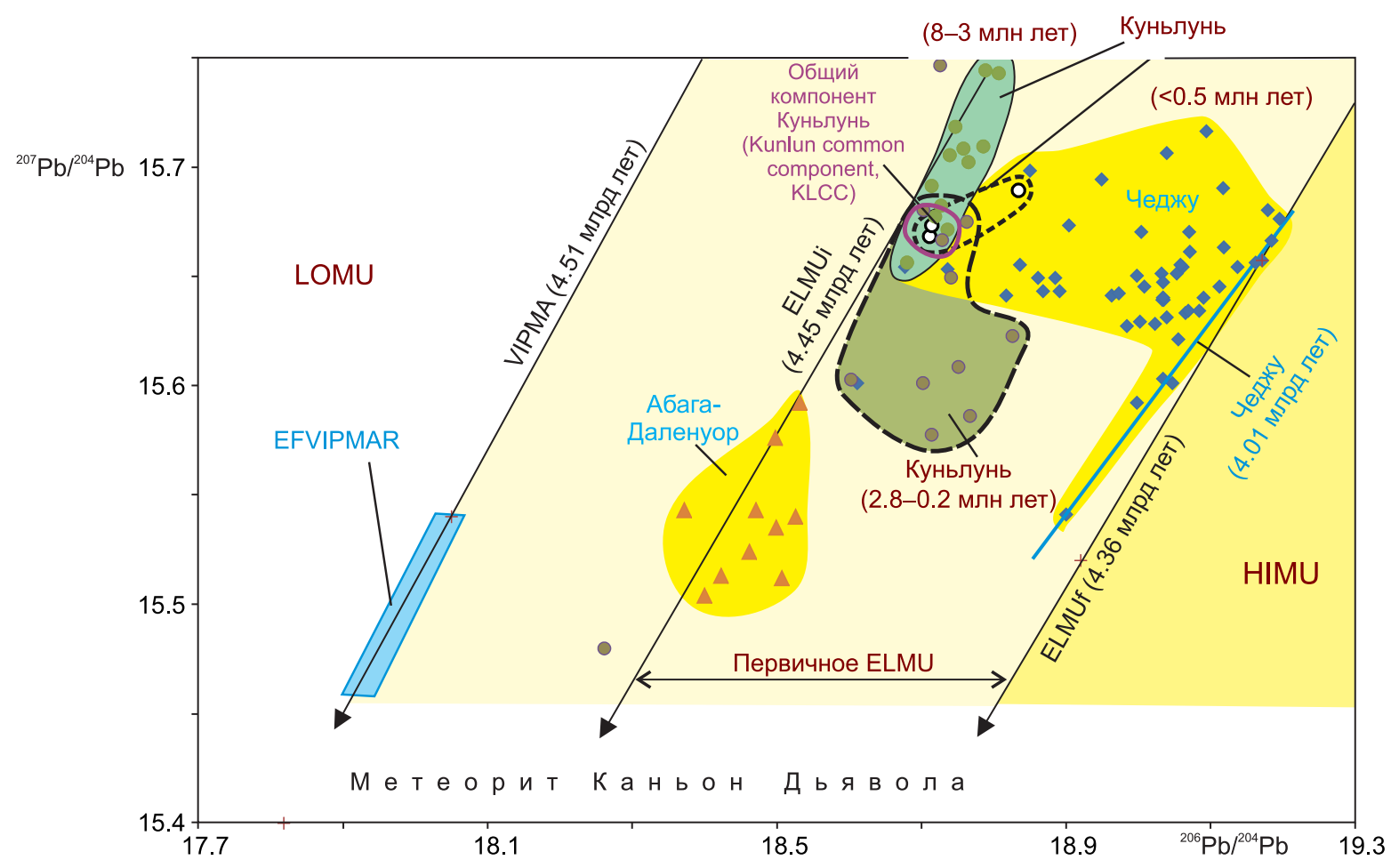

Рис. 12. Изотопные отношения ураногенного $\mathrm{Pb}$ в породах расплавных аномалий Чеджу, Куньлунь и АбагаДаленуор. Возрастной интервал первичного ELMU- 4.45-4.36 млрд лет назад (ELMUi - начало и ELMUf - окончание). Общий компонент Куньлунь: ${ }^{207} \mathrm{~Pb} /{ }^{204} \mathrm{~Pb}=15.67,{ }^{206} \mathrm{~Pb} /{ }^{204} \mathrm{~Pb}=18.71$. Данные [Turner et al., 1996; Park et al., 2005; Tatsumi et al., 2005; Zhang et al., 2008; Brenna et al., 2012].

Fig. 12. Uranogenic $\mathrm{Pb}$ isotope ratios in rocks from the Jeju, Kunlun, and Abaga-Dalenuor melting anomalies. The age interval of primary ELMU is constrained between 4.45 and 4.36 Gir ago (ELMUi - initial, and ELMUf - final). The Kunlun common component: ${ }^{207} \mathrm{~Pb} /{ }^{204} \mathrm{~Pb}=15.67,{ }^{206} \mathrm{~Pb} /{ }^{204} \mathrm{~Pb}=18.71$. Data from [Turner et al., 1996; Park et al., 2005; Tatsumi et al., 2005; Zhang et al., 2008; Brenna et al., 2012].

(15.601-15.690). Массовые определения изотопных отношений $\mathrm{Pb}$ в вулканических породах о-ва [Tatsumi et al., 2005; Brenna et al., 2012] дали хаотический разброс точек при повышенных значениях ${ }^{207} \mathrm{~Pb} /{ }^{204} \mathrm{~Pb}$ с отчетливым ограничением фигуративного поля линией, проходящей через точки переходных базальтов с наклоном, соответствующим возрасту 4.01 млрд лет.

По гипотезе [Tatsumi et al., 2005], вулканизм о-ва Чеджу порожден мантийным плюмом, внедрившимся в тылу островной дуги Северо-Восточного Хонсю. Хотя корневая часть расплавной аномалии Чеджу не имеет подтверждения сейсмической томографией, материал ELMU базальтов может предварительно интерпретироваться в пользу плюмовой гипотезы. Фигуративное поле пород Чеджу протягивается от состава KLCC до линии ELMUf, близкой к изохронной линии этой расплавной аномалии, соответствующей возрасту 4.01 млрд лет. Такое распределение точек отражает смешение материала KLCC с материалом ELMUf, частично переработанным около 4 млрд лет назад.
Расплавная аномалия Абага-Даленуор находится в Северном Китае. Породы базальтового, щелочнобазальтового и базанитового состава датированы интервалом 15.42-0.16 млн лет. На диаграмме изотопных отношений ураногенного $\mathrm{Pb}$ фигуративные точки пород смещены от состава KLCC вдоль линии ELMUi. Следовательно, источник вулканических пород близок по возрасту источнику куньлуньских пород.

Вулканическое поле Абага-Даленуор пространственно соответствует отчетливо выраженной аномалии низких скоростей S-волн в верхней мантии модели [Yanovskaya, Kozhevnikov, 2003]. В глубинной модели [Kozhevnikov et al., 2014] снижения скоростей в переходном слое под вулканическим полем Абага-Даленуор не обнаружено, т.е. статус первичной расплавной аномалии сейсмической томографией не подтвержден. Обращает на себя внимание смещение фигуративного поля Абага-Даленуор относительно фигуративных полей Чеджу вдоль линии ELMUi, подобное смещению вдоль линии VIPMA фигуративного поля протолитосферного источника Удокана относительно фигуративного 
поля мезосферного источника Гоби. Если такая аналогия справедлива, источник пород Чеджу может относиться к мезосфере, а источник пород Абага-Даленуор - к протолитосфере.

\subsection{2. Эволюционированные составы ELMU}

Источники этого типа с повышенным $238 \mathrm{U} / 204 \mathrm{~Pb}$ проявлены в вулканических породах впадины Туюн, крупной магматической провинции Декан и группы вулканических полей п-ова Индокитай.

Во впадине Туюн (Китайский Тянь-Шань) извергалась вулканическая серия пикробазальт-трахибазальт-базанит-фонотефрит-фонолит на протяжении длительного временного интервала 12246 млн лет назад. Вся вулканическая серия была производной плавления малоглубинного безгранатового мантийного источника [Rasskazov et al., 2015]. По изотопным отношениям $\mathrm{Pb}$ различаются два тренда. Один из них аппроксимируется линией с наклоном, соответствующим возрасту $4.022 \pm 0.180$ млрд лет, другой, при сопоставимой протяженности, дает нижний предел наклона линии, соответствующий возрасту около 3.392 млрд лет. Тренды пересекаются вблизи траектории VIPMA, обозначая общий компонент Туюн (Tuyon common component, TCC), находящийся заметно ниже EFVIPMAR. Тренды пород впадины Туюн сходятся к составу ТСС и расщепляются к составу KLCC (рис. 13, a).

Вулканические породы адакитового состава, извергавшиеся в террейне Лхаса (Южный Тибет) во временном интервале 26-12 млн лет назад, аппроксимируются линией с наклоном 3.983 млрд лет, проходящей через ТСС. Близкий наклон (возраст 3.857 млн лет) дает тренд точек базанитов террейна Сонгпан-Ганзи (Северный Тибет, Куньлунь) возрастного интервала 14.8-0.28 млн лет, совпадающий с KLCC.

Особое положение на диаграмме изотопных отношений ураногенного $\mathrm{Pb}$ занимает высоко- $\mathrm{Mg}$ серия неизмененных пород Южного Тибета возрастом 40-38 млн лет, обнаруживающая более пологий тренд с наклоном 2.806 млрд лет. Параллельно этому тренду группируется большинство точек адакитов террейна Лхаса (рис. 13, б).

Разновозрастные кайнозойские породы Индокитая по наклону тренда, соответствующему возрасту около 1.9 млрд лет, сопоставляются с OIB+MORB, но, в отличие от преобладающих базальтов плато Декан, образуют поле точек, заключенное между траекториями VIPMA и ELMU (4.36 млрд лет) (рис. 14). Мел-палеогеновые породы Центрального Декана (Индия) отличаются сравнительно широким разбросом точек на диаграмме изотопных отношений ураногенного $\mathrm{Pb}$ при их максимальной концентрации между траекторией
VIPMA и полосой ELMU (рис. 15). Прохождение тренда через EFVIPMAR отражает вовлечение в плавление материала вязкой протомантии.

Наиболее протяженный тренд базальтов рифта Тапи аппроксимируется линией с наклоном, соответствующим возрасту $2.762 \pm 0.180$ млрд лет. Менее протяженный тренд правее траектории VIPMA с меньшим наклоном (около 2 млрд лет) дают толеитовые базальты Куч. На этом тренде находится состав KLCC. Такой же наклон дают траппы Центрального Декана. Эти тренды сопоставляются с трендом OIB+MORB (cм. рис. 1). Смещение точек щелочных базальтов Куч ниже тренда толеитовых базальтов с выстраиванием в более пологий тренд характеризует проявление источника молодой конвектирующей мантии.

\section{4. ОБСУЖДЕНИЕ}

\section{1. ДРЕВНЕЙШИЕ РАДИОИЗОТОПНЫЕ МЕТКИ В ПОРОДАХ ПОВЕРХНОСТИ ЗЕМЛИ}

Первичная поверхность Земли разрушена экзогенными процессами, поэтому породы, образовавшиеся в ранней Земле, долгое время не были известны. Прорыв в идентификации наиболее древних пород планеты наметился в конце 1980-х гг., когда U-Pb-методом (SHRIMP) по цирконам были датированы гнейсы Акаста (Канада) возрастным интервалом 4.03-3.94 млрд лет [Bowring, Housh, 1995; Bowring, Williams, 1999]. Позже методом лазерной абляции в сочетании с плазменной массспектрометрией и с применением ионного зонда высокого разрешения для ксенокристов циркона из гнейсов Акаста был определен также U-Pb возраст, составивший около 4.2 млрд лет [Iizuka et al., 2006]. В нескольких местонахождениях Западной Австралии были обнаружены обломочные цирконы с предельным U-Pb возрастом 4.276 млрд лет и встречено единственное зерно с возрастом 4.404 \pm 0.008 млрд лет [Wilde et al., 2001]. К настоящему времени обломочные цирконы найдены в разных регионах мира [Kuz'min, 2014].

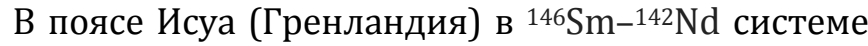
в сочетании с начальным значением эпсилон ${ }^{143} \mathrm{Nd}$ получена оценка времени дифференциации мантии $4.460 \pm 0.115$ млрд лет. Предполагалось, что это раннее $\mathrm{Sm} / \mathrm{Nd}$ фракционирование обозначило стадию аккреции Земли [Caro et al., 2003]. В зеленокаменном поясе Нуввуагиттук (Квебек, Канада) были найдены псевдоамфиболиты, представляющие собой материал, обогащенный несовместимыми элементами вскоре после завершения первичной планетарной аккреции. Для этих пород была получена изохронная ${ }^{142} \mathrm{Nd} /{ }^{146} \mathrm{Sm}-{ }^{146} \mathrm{Sm} /{ }^{142} \mathrm{Nd}$-датировка 

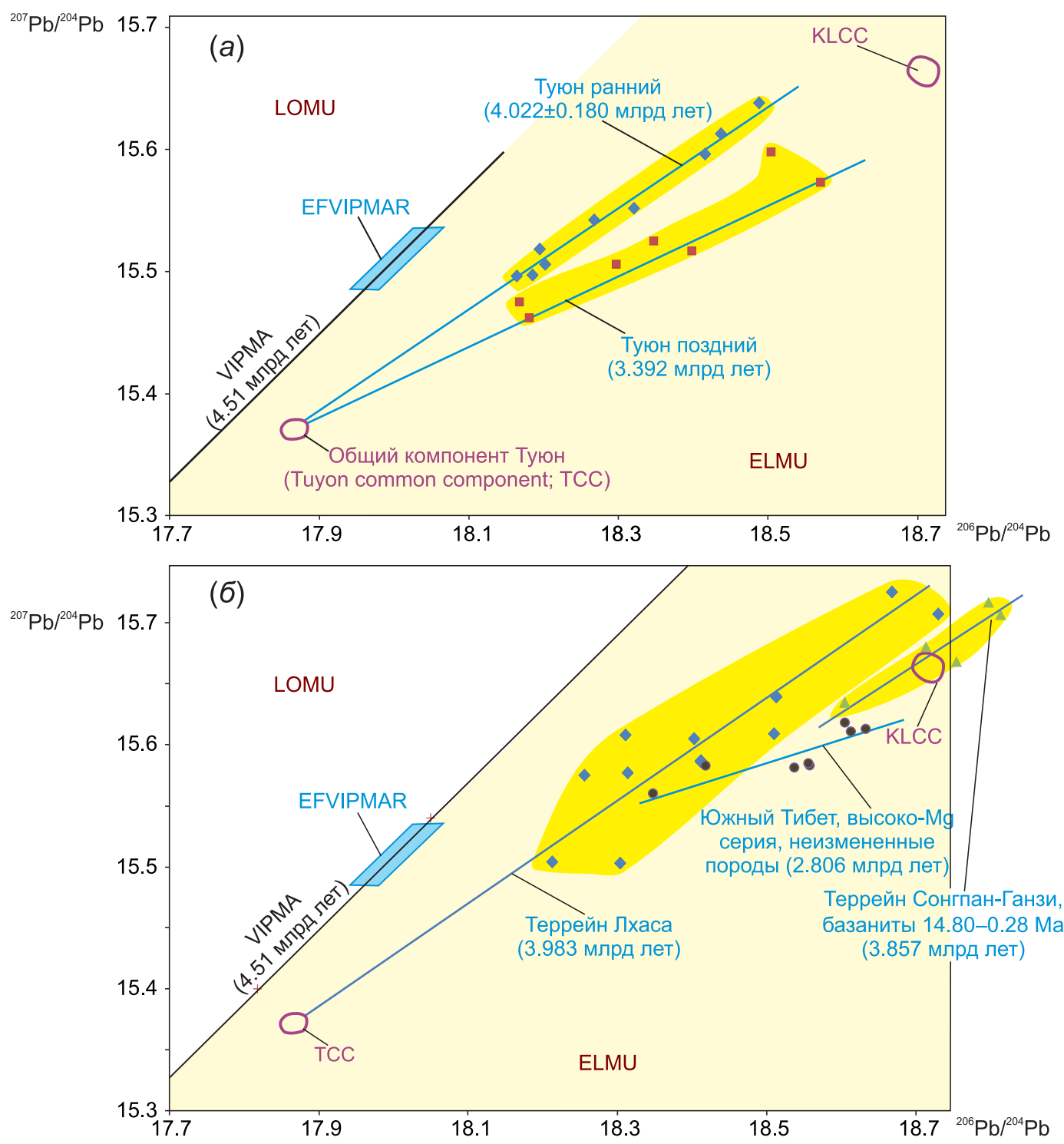

Рис. 13. Изотопные отношения ураногенного Рb в породах впадины Туюн (Китайский Тянь-Шань) (a) и Тибета (б). Данные из работ [Sobel, Arnaud, 2000; Ji et al., 2006; Guo et al., 2006, 2007; Gao et al., 2008; Zhang, Guo, 2016].

Fig. 13.Uranogenic $\mathrm{Pb}$ isotope ratios of rocks from the Tuyon basin (Chinese Tien Shan) (a) and Tibet (б). Data from [Sobel, Arnaud, 2000; Ji et al., 2006; Guo et al., 2006, 2007; Gao et al., 2008; Zhang, Guo, 2016].

$4280+53 /-81$ млн лет [O’Neil et al., 2008]. В блоке Саглек (Лабрадор, Канада) в ${ }^{176} \mathrm{Lu} /{ }^{177} \mathrm{Hf}-$ системе определен эпизод дифференциации мантийного материала свиты Нуллиак $4.40 \pm 0.03$ млрд лет назад [Morino et al., 2018].

На территории Азии, в китайской части СиноКорейского кратона (Аншан), обнаружены остатки коры, соответствующие границе гадея и архея [Liu et al., 1992]. В блоке Чангду (Северный Цьянтанг, Тибет) найдены обломочные цирконы возрастом $3.981 \pm 0.009$ млрд лет. По двустадийной модели изотопов Нf получены оценки возраста в интервале 4.316-3.784 млрд лет. Подобные обломочные цирконы с возрастом 4.1-4.0 млрд лет найдены в Гималаях на территории, некогда входившей в состав
Восточной Гондваны [He et al., 2011]. В ордовикских игнимбритах Северо-Циньлинского пояса Китая охарактеризованы ксенокристы циркона, содержащие ядра возрастом более 3.9 млрд лет с модельным Lu/Hf-возрастом до 4.45 млрд лет, сходные по этим цифрам с наиболее древними обломочными цирконами Джек Хиллз [Diwu et al., 2013].

\section{2. ПРОТОЛИТОСФЕРА И ПРОТОМАНТИЯ АЗИИ В КОНТЕКСТЕ СОБЫТИЙ ПЕРВИЧНОЙ АККРЕЦИИ ЗЕМЛИ}

После образования Солнца $4567.3 \pm 0.16$ млн лет назад [Connelly et al., 2012] Протоземля разрасталась посредством аккреции планетезималей. В результате гигантского выделения энергии в Сол- 


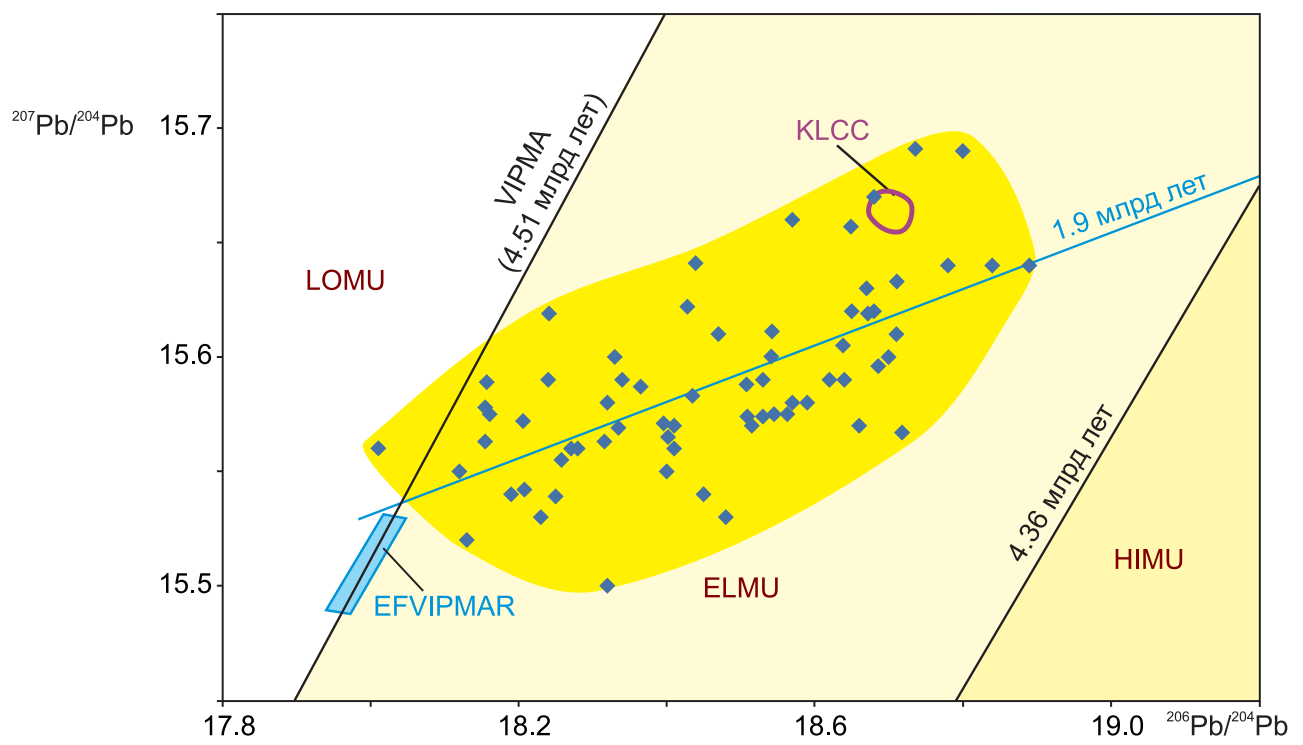

Рис. 14. Изотопные отношения ураногенного Рb в кайнозойских вулканических породах Индокитая. Данные из работ [Hoang et al., 1996, 2013].

Fig. 14. Uranogenic $\mathrm{Pb}$ isotope ratios of volcanic rocks from Indochina. Data from [Hoang et al., 1996, 2013].

нечной системе Земля расплавилась и представляла собой глобальный магматический океан, в котором сидерофильные элементы распределялись в ядро [Hart, Gaetani, 2006; Rubie et al., 2011; Morbidelli et al., 2018]. Ядро выделялось в течение 30 млн лет [Kleine et al., 2009]. В моделях растущей Земли каж- дая добавка металлов извне во время ее аккреции уравновешивалась со всей мантией с отторжением в ядро [Wade, Wood, 2005, 2016; Wood et al., 2006; Rubie et al., 2011]. Точное время гигантского импакта, повлекшего за собой образование Луны, не известно. Предполагается, что это событие про-

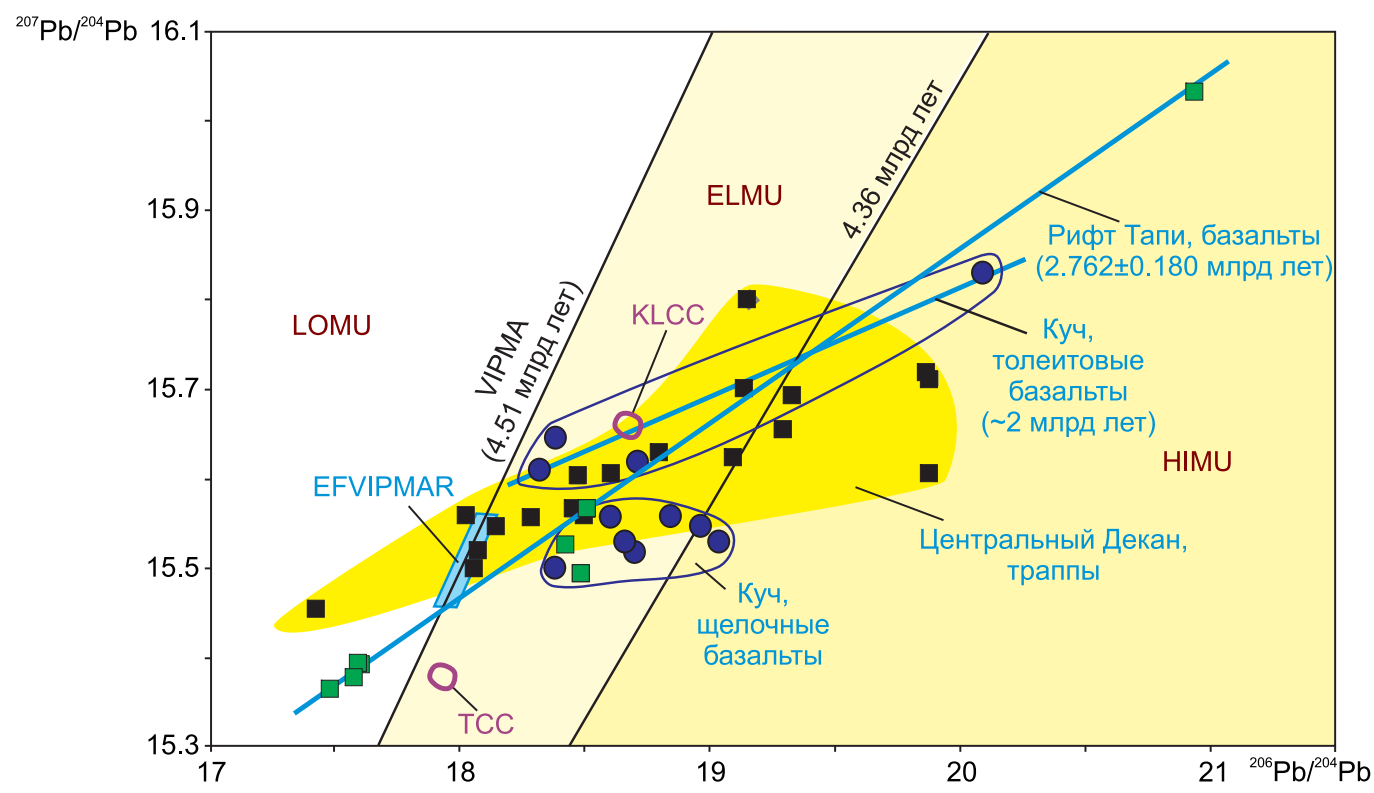

Рис. 15. Изотопные отношения ураногенного $\mathrm{Pb}$ в породах Индостана. Данные из работ [Chardrasekharam et al., 1999; Paul et al., 2008; Peng et al., 2014; Sen et al., 2009; Sheth, Melluso, 2008].

Fig. 15. Uranogenic Pb isotope ratios in rocks from Hindustan. Data from [Chardrasekharam et al., 1999; Paul et al., 2008; Peng et al., 2014; Sen et al., 2009; Sheth, Melluso, 2008]. 
изошло не позже чем через 60 млн лет после образования Солнца.

Изучение Луны показало, что на раннем этапе эволюции Солнечной системы планеты земной группы испытывали многочисленные импактные события. Дополнительный приток метеоритов после образования ядра рассматривается как поздний шпон (late veneer), отражающийся в избытке высокосидерофильных элементов (Pt, Re, Os, Au) в мантии Земли [Chou, 1978; Kleine et al., 2009]. По крайней мере, часть позднего шпона добавлялась к мантии при формировании источника базальтов Исуа (Гренландия) до 3.8 млрд лет назад [Dale et al., 2012, 2017; Willbold et al., 2011; Touboul et al., 2012; Kruijer et al., 2015].

Предлагаются различные модели первичной аккреции Земли. Так, в построениях [Albarède, 2009] поздний шпон ограничен временным интервалом 80-130 млн лет после образования Земли как космического тела (т.е. интервалом 4.487-4.437 млрд лет назад). В другой (двухступенчатой) модели ABEL (advent of bio-elements) [Maruyama, Ebisuzaki, 2017] предполагается начальная планетарная аккреция сухого энстатитового хондритоподобного материала и более позднее (в интервале 4.37-4.20 млрд лет назад) добавление биоэлементов (воды), связанных в основном с углистыми хондритами.

По результатам изучения лунных пород [Sprung et al., 2013] допускается сильное плавление Земли 4.43-4.35 млрд лет назад. Этот интервал обозначен модельным Lu-Hf возрастом кристаллизационного остатка резервуара urKREEP (обогащенного несовместимыми элементами К, РЗЭ, Р) с хондритовым отношением Lu/Hf. При датировании лунных образцов в Lu-Hf- и Sm-Nd-изотопных системах [Gaffney, Borg, 2014] было выделено обширное крупномасштабное магматическое событие около 4.37 млрд лет назад, которое в дальнейшем выразилось в кристаллизации лунного магматического океана. Это событие Луны подтвердилось $\mathrm{Pb}-\mathrm{Pb}$ датировкой 4.376 \pm 0.018 млрд лет пород резервуара urKREEP и железистых анортозитов (FAN) [Snape et al., 2016].

Интервал растянувшейся во времени аккреции Земли [Chou, 1978; Bottke et al., 2010; Morbidelli et al., 2018] включает ее позднюю тяжелую бомбардировку (LHB, Late Heavy Bombardment), обозначенную скачком частоты импактов лунных кратеров в интервале 4.1-3.8 млрд лет назад. Предполагается, что поздняя бомбардировка отразила эпизод поступления космических тел с периферии Солнечной системы на планету Земля и другие планеты земной группы [Morbidelli et al., 2018]. Общая масса материала поздней аккреции (позднего шпона) оценивается в 1.0-2.5 \% массы планеты [Bottke et al., 2010; Marchi et al., 2018]. В построениях [Albarède et al., 2009; Maruyama, Ebisuzaki, 2017] событие LHB считается незначительным. Между тем рудный $\mathrm{Pb}$ в раннедокембрийской коре Гарганского блока и южного края Сибирской платформы с параметрами $T$, соответственно, 4.31 и 3.82 млрд лет характеризует два события, запечатленные в замыкании $\mathrm{U}-\mathrm{Pb}$-изотопной системы ранней Земли. Событие $T=4.31$ млрд лет назад соответствовало завершению планетарной аккреции Земли, событие $T=3.82$ млрд лет назад - завершению поздней тяжелой бомбардировки [Rasskazov et al., 2010].

\section{3. РЕЗЕРВУАРЫ LOMU, ELMU И HIMU В ЭВОЛЮЦИИ ЗЕМЛИ}

В дискуссии о происхождении компонента HIMU допускались различные варианты повышения ${ }^{238} \mathrm{U} /{ }^{204} \mathrm{~Pb}(\mu)$ в глубинных источниках в связи с аномальным обогащением ураном или обеднением свинцом пород субдуцирующей океанической плиты. Комплексирование изотопных систем с определением времени образования ядра по соотношению изотопов $\mathrm{Hf}$ и $\mathrm{W}$ показало, что ${ }^{238} \mathrm{U} /{ }^{204} \mathrm{~Pb}$ возросло вследствие концентрации $\mathrm{Pb}$ в ядре как халькофильного элемента. Подчеркивалось значение этого процесса на раннем этапе становления Земли [Murphy et al., 2003; Albarède, 2009; Hart, Gaetani, 2006]. Судя по ярко выраженному тренду диаграммы ${ }^{207} \mathrm{~Pb} /{ }^{204} \mathrm{~Pb}-206 \mathrm{~Pb} /{ }^{204} \mathrm{~Pb}$, процесс отторжения $\mathrm{Pb}$ от мантии в ядро резко активизировался около 2 млрд лет назад [Hart, Gaetani, 2006]. Протяженный тренд HIMU с наклоном около 1.77 млрд лет получил название Линии Отсчета Северного Полушария (Northern Hemisphere Reference Line, NHRL) [Hart et al., 1986]. Такой же наклон был обозначен прежде для резервуара MORB [Tatsumoto, 1978].

Добавка космогенного материала в виде позднего шпона реализовалась в эволюции рудного $\mathrm{Pb} \mathrm{c}$ высоким $\mu$ на малых глубинах Земли (в ранней литосфере) около 4.31 и 3.82 млрд лет назад [Rasskazov et al., 2010], но не отразилась в заметном повышении ${ }^{238} \mathrm{U} /{ }^{204} \mathrm{~Pb}$ в источниках вулканических пород новейших расплавных аномалий с соответствующим уменьшением наклона линий относительно геохроны, как должно было случиться, если бы глубинная часть мантии Протоземли оставалась расплавленной и конвектирующей продолжительное время. Секвестр $\mathrm{Pb}$ в ядро, по-видимому, сопровождался повышением $\mathrm{U} / \mathrm{Pb}$ преимущественно в нижней части мезосферы, сопредельной с ядром, что с течением времени выразилось в развитии компонента HIMU OIB. Следовательно, HIMU служит показателем глубинного мантийного источника OIB. Отметим также, что в основе 


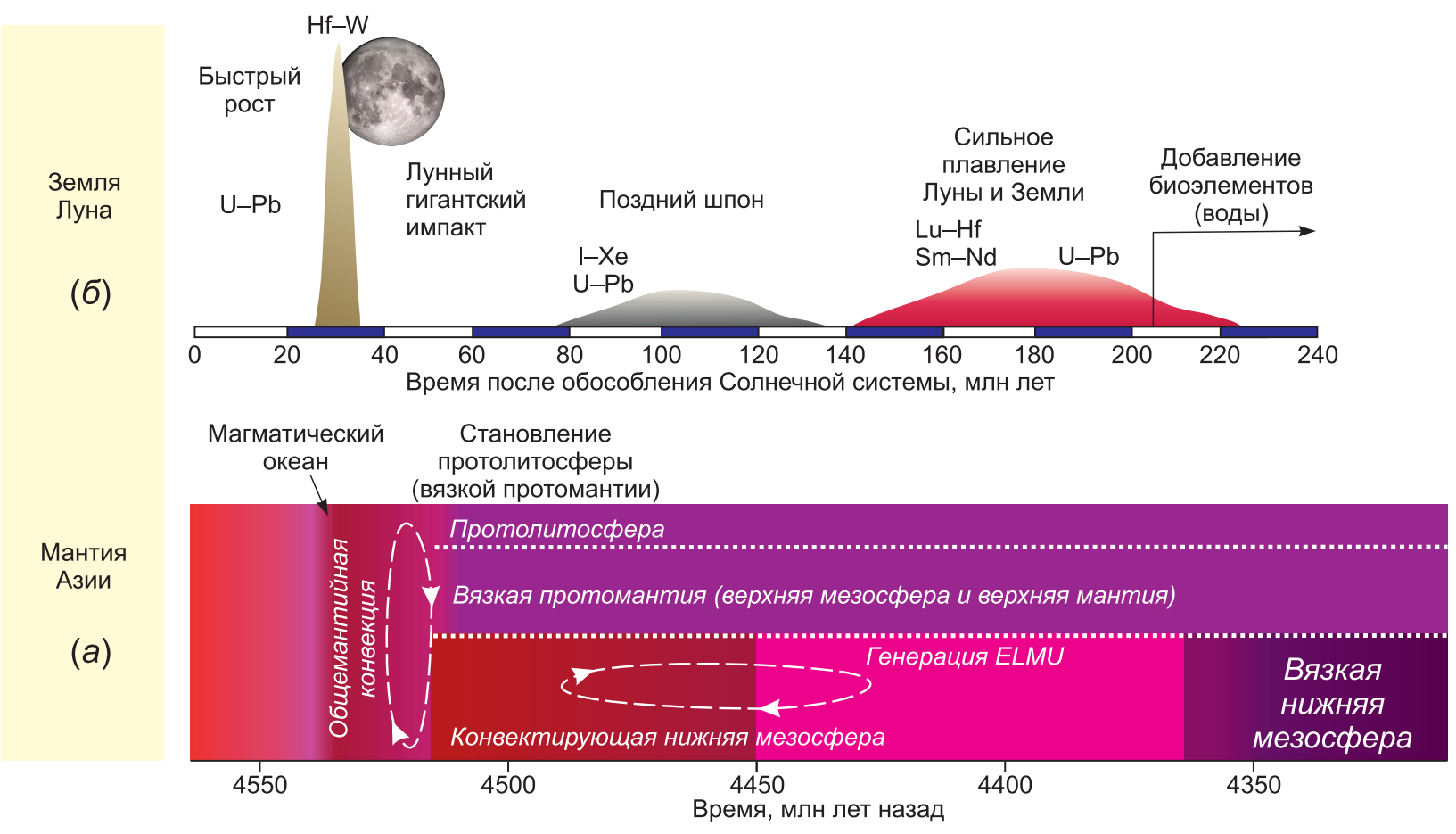

Рис. 16. Становление протолитосферы (вязкой протомантии) Азии 4.51 млрд лет назад и более позднее поддерживание низкой вязкости в нижней мезосфере (a) в контексте основных событий первичной аккреции Земли (б). Последовательность событий ранней Земли на панели (a) обозначена по работам [Albarède, 2009; Sprung et al., 2013; Gaffney, Borg, 2014; Snape et al., 2016; Maruyama, Ebisuzaki, 2017].

Fig. 16. Formation of the protolithosphere (viscous protomantle) of Asia at 4.51 Gyrago, and later maintaining of the low viscosity in the lower mesosphere $(a)$ in the context of the main events during the primary accretion of the Earth (б). The sequence of the early Earth events in panel (a) is indicated after [Albarède, 2009; Sprung et al., 2013; Gaffney, Borg, 2014; Snape et al., 2016; Maruyama, Ebisuzaki, 2017].

первичного прогноза происхождения базальтовых расплавов океанических островов из глубокой части мантии было заложено их сравнение с расплавами базальтов малоглубинных источников мантии под срединными океаническими хребтами [Morgan, 1971]. При наибольшей глубине компонента HIMU OIB и наименьшей - материала DMM MORB другие компоненты океанических базальтов (EM 1, EM2, FOZO) должны относиться к промежуточным глубинам мантии.

Генеральная Рb-изотопная систематика вулканических пород Азии выстраивается по аналогии с систематикой океанических базальтов. Материал VIPMA и производный от него материал LOMU сопоставляется с компонентами базальтов океанов, характеризующимися низкими значениями

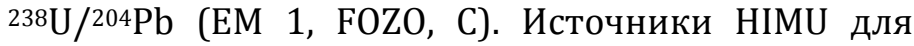
Азии не характерны, но важную роль в ней играют источники ELMU. Полоса, отклонившаяся от геохроны с повышением $238 \mathrm{U} / 204 \mathrm{~Pb}$, зарегистрирована во временном диапазоне от 4.45 до 4.36 млрд лет в источниках расплавных аномалий Куньлунь, Чеджу и Абага-Даленуор. Материал из источника ELMU находился в той части мезосферы, которая испыта- ла потери $\mathrm{Pb}$ в результате его секвестра в ядро. Обозначенный временной интервал первичного ELMU совпал с интервалом сильного плавления Луны и Земли (рис. 16).

Протолитосфера представлена материалом VIPMA возрастом 4.51 млрд лет в Удоканской расплавной аномалии края Алданского щита и, возможно, материалом ELMU в источнике расплавной аномалии Абага-Даленуор. Последний из них находится во Внутренней Азии, в отличие от расплавных аномалий Куньлунь и Чеджу, расположенных вблизи межплитных границ.

$\mathrm{Pb}$-изотопное замыкание источников вязкой верхней мантии регистрируется материалом VIPMA и ELMU начиная с 4 млрд лет назад. Новообразование объемов верхней мантии замкнутой $\mathrm{U}-\mathrm{Pb}$-изотопной системы в источниках вулканических пород Азии отчетливо выражено в шести временных интервалах: I. 4.51-4.36 млрд лет назад, II. 4.0-3.7 млрд лет назад, III. 2.9-2.6 млрд лет назад, IV. 2.0-1.8 млрд лет назад, V. около 0.66 млрд лет назад и VI. <0.09 млрд лет назад.

C IV интервалом совпадает оценка возраста ли-

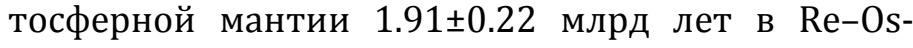




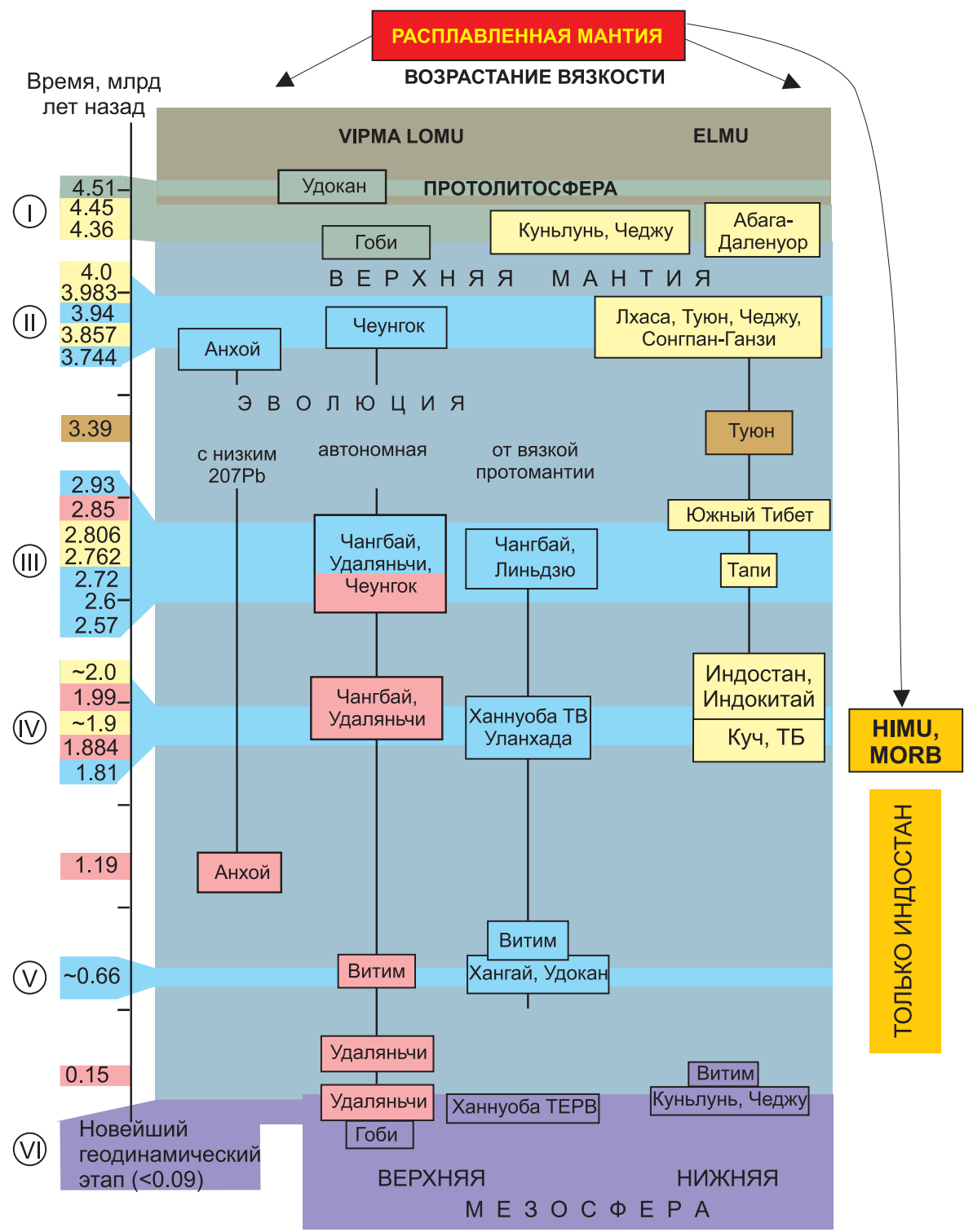

Рис. 17. Временное распределение протолитосферных, верхнемантийных и мезосферных источников вулканических пород новейшего геодинамического этапа Азии. Римскими цифрами в кружках обозначено шесть временных интервалов становления верхней мантии Азии, в которые объединены вулканические территории голубых и желтых панелей. Розовые панели показывают источники, материал которых был преобразован и отделен от VIPMA, светло-коричневая панель лав Туюн подобный случай эволюционированного и индивидуализированного источника ELMU.

Fig. 17. Temporal distribution of protolithospheric, upper mantle, and mesospheric sources for the volcanic rocks of the latest geodynamic stage in Asia. Roman numerals in circles indicate six time intervals for the formation of the upper mantle in Asia, in which the volcanic areas of the blue and yellow panels are combined. The pink panels show sources, material of which was evolved and separated from VIPMA; the light brown panel of the Tuyon lavas indicates a similar case of the evolved and separated ELMU source.

изотопной системе по сульфидам из мантийных ксенолитов вулканических пород поля Ханнуоба [Gao et al., 2008]. Эпизод 3.39 млрд лет, обозначенный для базальтов Туюн как наложенный на источник ELMU возрастом 4 млрд лет, не имел самостоятельного значения события, связанного с генерацией нового мантийного объема. В это время перерабатывался уже имевшийся материал источника ELMU. Отдельной вторичной изохроной 1.19 млрд лет базальтов провинции Анхой зарегистрировано преобразование материала верхнемантийного источника с трендом L0207, образовавшимся около 3.7 млрд лет назад. Подобная переработка материала определена также в рамках интервалов новообразования верхней мантии в источниках вулканических пород автономной эволюции: Чангбай (общий резервуар 2.93 млрд лет, переработка около 1.99 млрд лет назад) и Удаляньчи (общий резервуар 1.884 млрд лет, переработка около 0.15 млрд лет назад и позже) (рис. 17). Материал ELMU зарегистрирован в I-IV и VI интервалах становления верхней мантии Азии. По-видимому, секвестр $\mathrm{Pb}$ из мезосферы был наиболее интенсивным в V интервале, что привело к глобальному распространению HIMU OIB и MORB. В целом из полученных $\mathrm{Pb}$-изотопных данных по вулканическим породам следует вывод о проявлении трех главных этапов в развитии Земли: 1) планетарной аккреции 4.5673-4.510 млрд лет назад, 2) развития континентальных доменов мезосферы и верхней мантии 4.45-1.8 млрд лет назад и 3) глобальной тектоники <1.8 млрд лет назад (рис. 18).

\section{4. ДОМЕНЫ LOMU И ELMU}

Первичные процессы в недифференцированной силикатной мантии запечатлены траекторией 
Общемантийная конвекция

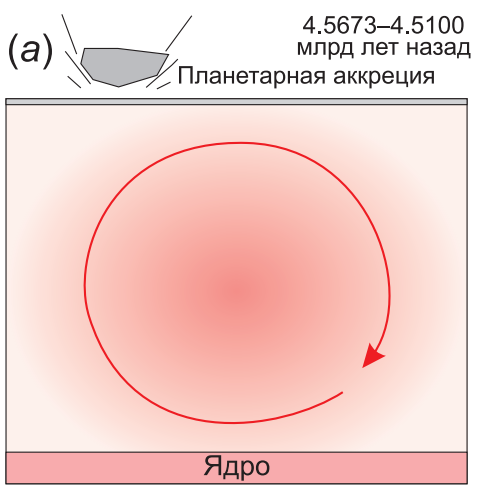

Развитие континентального домена

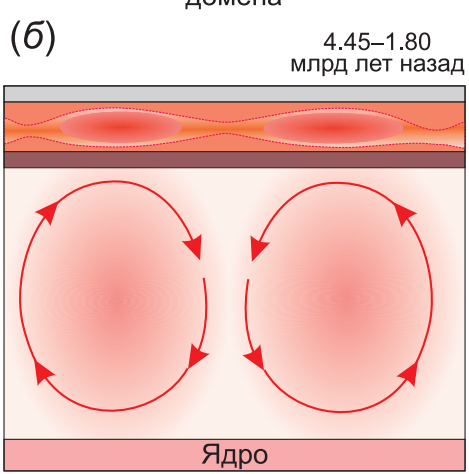

Глобальная тектоника

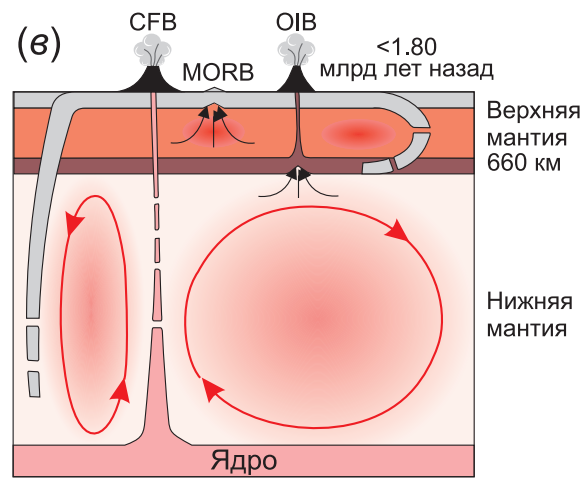

Рис. 18. Три главных этапа развития Земли (по Рb-изотопной систематике источников вулканических пород новейшего геодинамического этапа Азии). Модифицированная схема [Allègre, 1997, 2002]. CFB - Continental Flood Basalts.

Fig. 18. Three main stages of the Earth development (from Pb-isotope systematics of sources for volcanic rocks from Asia of the latest geodynamic stage). The scheme is modified after [Allègre, 1997, 2002]. CFB - Continental Flood Basalts.

VIPMA. Изотопная эволюция $\mathrm{Pb}$ направлена в область LOMU. Породы на траектории не затронуты сульфидным секвестром Pb в ядро. Между тем часть мезосферы подвергалась сульфидному перераспределению $\mathrm{Pb}$ в ядро с возрастанием $238 \mathrm{U} / 234 \mathrm{~Pb}$ при эволюции материала в области ELMU. На новейшем геодинамическом этапе источники вулканических пород с мантийными компонентами LOMU и ELMU были в целом пространственно обособлены друг от друга. Источники ELMU-типа представлены доменом южной части Азии, включающей Индокитай, Индостан, Тибет и Тянь-Шань, источники LOMU - доменом Японско-Байкальского геодинамического коридора. В домене ELMU мате-

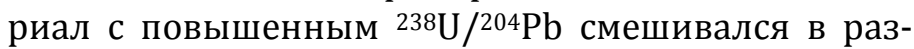
личных пропорциях с недифференцированным материалом VIPMA.

В Японско-Байкальском геодинамическом коридоре выделилась также линия расплавных аномалий Чеджу, Линьдзю, Абага-Даленуор, Витим и Удокан, в которой, наряду с источниками LOMU, проявились источники ELMU (рис. 19). Вдоль линии от Чеджу до Витима материал ELMU проявился в наиболее молодых извержениях с максимальной продолжительностью около 15 млн лет в средней части линии на поле Абага-Даленуор. В Удоканской расплавной аномалии источник ELMU-типа был активен в ее юго-восточной и центральной части в интервале 9-3 млн лет назад и сменился поступлением материала VIPMA из источника протолитосферы. Для выявления механизма инициации источников ELMU в ЧеджуВитимской линии как выражения новейших глубинных процессов на юном фланге геодинамического коридора необходимо более детальное сравнительное изучение пространственно-временного характера активности источников LOMU- и ELMU-типа всего фланга.

Из датировок вторичных изохрон $\mathrm{Pb}$ следует вывод о шести этапах преобразования мантийных источников, каждый из которых повлек за собой либо преобразование материала верхней мантии, либо поднятие материала из мезосферы в верхнюю мантию с его последующей инкубацией. Консервативное развитие вязкой мантии выразилось в последовательном пополнении домена LOMU порциями материала, производного VIPMA, и домена ELMU - порциями материала с повышенным 238U/204Pb. Домен LOMU осложнялся эпизодическим внедрением материала ELMU. На новейшем геодинамическом этапе материал VIPMA поднимался из мезосферы в первичных расплавных аномалиях Гоби, Ханнуоба, Уланхада и Западно-Забайкальской и материал ELMU - в первичных расплавных аномалиях Куньлуньской, Витимской и Чеджу. Наиболее очевидно распространение первичного расплавного материала мезосферы на вулканических полях Гоби, Западного Забайкалья, Куньлуня и Чеджу.

Тренд HIMU, свойственный океаническим базальтам, на территории Азии слабо выражен только в траппах Декан, но ярко проявлен, к примеру, в кайнозойских анорогенных вулканитах Средиземноморья, Аравийской плиты и сопредельных территорий, на которых распространен материал Афарского плюма. Общему мантийному резервуару этих территорий присвоены значения HIMU ${ }^{206} \mathrm{~Pb} /{ }^{204} \mathrm{~Pb}=19.6-19.9,{ }^{207} \mathrm{~Pb} /{ }^{204} \mathrm{~Pb}=15.60-16.66$ [Granet et al., 1995; Bertranda et al., 2003; Lustrino, Wilson, 2007]. 


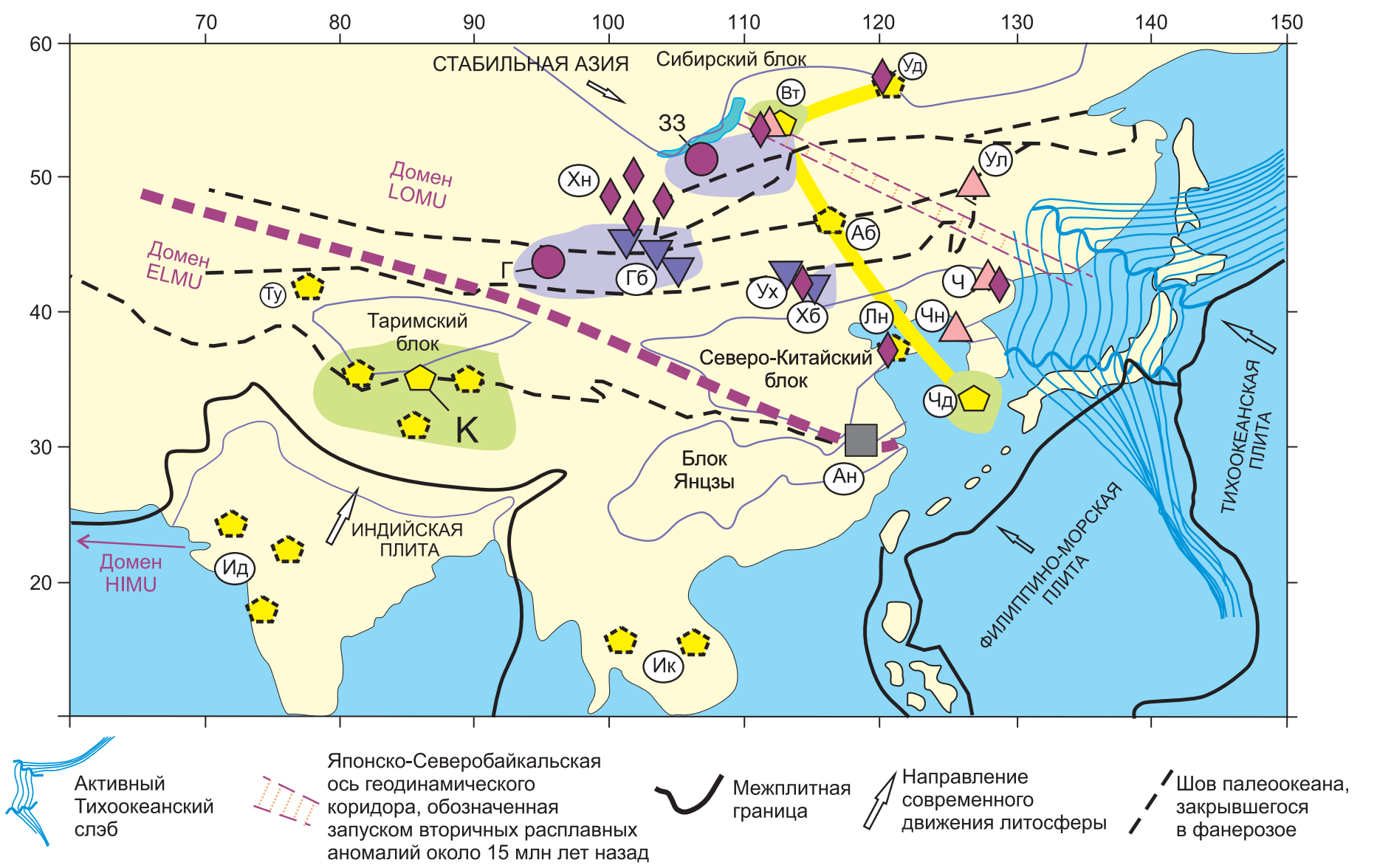

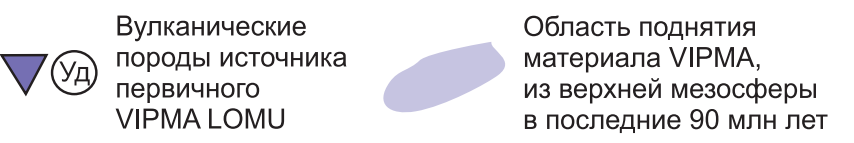

Вулканические породы источника LOMU верхней мантии или протолитосферы, производной VIPMA

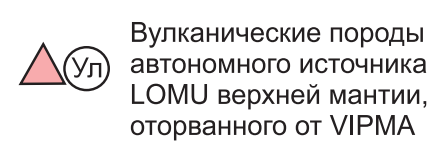

\begin{abstract}
Вулканические
породы источника
первичного ELMU
\end{abstract}
Вулканические породы источника с низким
(Aн) ${ }^{207} \mathrm{~Pb} /{ }^{204} \mathrm{~Pb}$

Область поднятия материала ELMU из нижней мезосферы в последние 90 млн лет

$$
D-\text { Граница доменов LOMU и ELMU }
$$

Линия ELMU

Рис. 19. Домены источников LOMU и ELMU вулканических пород Азии. Тренд HIMU, слабо выраженный в траппах Декан, проявился в кайнозойских анорогенных вулканитах европейской части Евразии. Буквенные обозначения вулканических территорий см. рис. 3.

Fig. 19. Domains of the LOMU and ELMU sources for volcanic rocks from Asia. The HIMU trend, poorly detectable in the Deccan traps, is well pronounced in Cenozoic anorogenic volcanic rocks from the Mediterranean region. See Fig. 3 for the symbols of volcanic areas.

\section{5.ЗАКЛЮЧЕНИЕ}

Разработанная $\mathrm{Pb}$-изотопная генеральная систематика мантийных источников вулканических пород Азии исходит из теории эволюции Земли с меняющейся вязкостью мантийных слоев. Этот процесс запечатлен в открытой и замкнутой эволюции U-Pb-изотопной системы материала крупных доменов. Вязкость снижалась с переходом к конвекции, выражающейся в $\mathrm{Pb}$-изотопной гомогенизации материала. И наоборот, вязкость возрас- тала с прекращением конвекции и последующей дифференциацией материала, отражающейся в $\mathrm{Pb}$ изохронном строе фигуративных точек глубинных выплавок. Вариации изотопных отношений $\mathrm{Pb}$ в вулканических породах Азии интерпретированы в свете гипотезы секвестра $\mathrm{Pb}$ в сульфидах из мантии в ядро.

В мантийных источниках вулканических пород Азии идентифицирован материал протолитосферы и вязкой протомантии, образовавшейся после гигантского лунообразующего импакта около 
4.51 млрд лет назад. Ранние $\mathrm{Pb}$-изотопные метки резервуара ELMU, производные отделения $\mathrm{Pb}$ в сульфидах от силикатной мантии в ядро, определены во временном интервале 4.45-4.36 млрд лет, предположительно в верхнем слое ранней Земли и глубокой части вязкой мантии источников вулканических пород. По вторичным $\mathrm{Pb}-\mathrm{Pb}$ изохронам вулканических пород прослежена эволюция верхней мантии Азии от материала VIPMA и ELMU с 4 млрд лет назад до настоящего времени. Новообразованные объемы верхней мантии с замыканием $\mathrm{U}-\mathrm{Pb}$-изотопной системы в источниках вулканических пород Азии зафиксированы во временных интервалах 4.0-3.7 млрд лет назад, 2.9-2.6 млрд лет назад, 2.0-1.8 млрд лет назад, около 0.66 млрд лет назад и $<0.09$ млрд лет назад. В разных расплавных аномалиях определены $\mathrm{Pb}$-изотопные характеристики первичного и производного от него мантийного материала. На новейшем геодинамическом этапе материал VIPMA, поднимавшийся из мезосферы, обозначился в первичных расплавных аномалиях Гоби и Западно-Забайкальской, а материал ELMU - в первичных расплавных аномалиях Куньлуня и Чеджу.

Расплавные аномалии источников ELMU характеризуют домен нестабильной Южной Азии, расплавные аномалии источников LOMU - ЯпонскоБайкальский геодинамический коридор области перехода от нестабильной Азии к ее стабильному ядру. Позднекайнозойская эволюция Японско-Байкальского геодинамического коридора привела к рассечению домена LOMU Чеджу-Витимской линией источников ELMU. Выявленное пространственное наложение линии источников ELMU на домен LOMU геодинамического коридора свидетельству- ет о сложной мантийной динамике, полная расшифровка которой станет возможной после получения более подробной картины пространственновременных соотношений материала LOMU и ELMU в расплавных аномалиях Азии.

Благодаря консервативной специфике ураногенных изотопных отношений $\mathrm{Pb}$ в настоящей работе определена генеральная возрастная общность источников вулканических пород Азии в контексте эволюции Земли. Опубликованные работы, содержащие анализ вариаций не только изотопных отношений ${ }^{206} \mathrm{~Pb} /{ }^{204} \mathrm{~Pb},{ }^{207} \mathrm{~Pb} /{ }^{204} \mathrm{~Pb}$, но также ${ }^{208} \mathrm{~Pb} /{ }^{204} \mathrm{~Pb},{ }^{143} \mathrm{Nd} /{ }^{144} \mathrm{Nd},{ }^{87} \mathrm{Sr} /{ }^{86} \mathrm{Sr}$ и элементных отношений $\mathrm{Ce} / \mathrm{Pb}, \mathrm{Y} / \mathrm{Ho}, \mathrm{Nb} / \mathrm{U}, \mathrm{Th} / \mathrm{U}, \mathrm{Th} / \mathrm{Yb}, \mathrm{Ta} / \mathrm{Yb}$, $\mathrm{K} / \mathrm{Ta}, \mathrm{La} / \mathrm{Ta}, \mathrm{Zr} / \mathrm{Sm}, \mathrm{Hf} / \mathrm{Sm}, \mathrm{Zr} / \mathrm{Hf}$ в породах вулканических полей Азии, свидетельствуют о становлении мантийных источников геологического прошлого в расплавных аномалиях конвектирующей нижней мантии (плюмовых и переходного слоя), верхней мантии, литосферы, океанических слэбов или надслэбовых областей. Генетическая принадлежность обозначенной генеральной разновозрастной системы источников получит конкретизацию в последующих работах.

\section{6. БЛАГОДАРНОСТИ}

Авторы благодарят И.В. Ащепкова и С.И. Дриля за конструктивную критику рукописи, способствовавшую улучшению ее содержания. Работа выполнена в Китайско-Российском исследовательском центре Удаляньчи-Байкал по новейшему вулканизму и окружающей среде при поддержке РНФ (проект 18-77-10027).

\section{7. ЛИТЕРАTУРA / REFERENCES}

Albarède F., 2009. Volatile accretion history of the terrestrial planets and dynamic implications. Nature 461 (7268), 1227-1233. https://doi.org/10.1038/nature08477.

Albarède F., Ballhaus C., Blichert-Toft J., Lee C.-T., Marty B., Moynier F., Yin Q.-Z., 2013. Asteroidal impacts and the origin of terrestrial and lunar volatiles. Icarus 222 (1), 44-52. https://doi.org/10.1016/j.icarus.2012.10.026.

Allègre C.J., 1997. Limitation on the mass exchange between the upper and lower mantle: the evolving convection regime of the Earth. Earth and Planetary Science Letters 150 (1-2), 1-6. https://doi.org/10.1016/S0012-821X(97) 00072-1.

Allègre C., 2002. The evolution of mantle mixing. Transactions of the Royal Society of London. Series A: Mathematical, Physical and Engineering Sciences 360 (1800), 2411-2431. https://doi.org/10.1098/rsta.2002.1075.

Allègre C.J., 2008. Isotope Geology. Second edition. Cambridge University Press, Cambridge, 512 p.

Allègre C.J., Dupré B., Brévart O., 1982. Chemical aspects of the formation of the core. Philosophical Transactions of the Royal Society of London. Series A: Mathematical and Physical Sciences 306 (1492), 49-59. https://doi.org/10.1098/ rsta.1982.0065.

Basu A.R., Junwen W., Wankang H., Guanghong X., Tatsumoto M., 1991. Major element, REE, and Pb, Nd and Sr isotopic geochemistry of Cenozoic volcanic rocks of eastern China: implications for their origin from suboceanic-type mantle reservoirs. Earth and Planetary Science Letters 105 (1-3), 149-169. https://doi.org/10.1016/0012-821X (91)90127-4. 
Becker T.W., Kellogg J.B., O'Connell R.J., 1999. Thermal constraints on the survival of primitive blobs in the lower mantle. Earth and Planetary Science Letters 171 (3), 351-365. https://doi.org/10.1016/S0012-821X(99)00160-0.

Bertranda H., Chazotb G., Blichert-Toft J., Thorala S., 2003. Implications of widespread high- $\mu$ volcanism on the Arabian Plate for Afar mantle plume and lithosphere composition. Chemical Geology 198 (1-2), 47-61. https://doi.org/ 10.1016/S0009-2541(02)00418-7.

Blichert-Toft J., Zanda B., Ebel D.S., Albarède F., 2010. The solar system primordial lead. Earth and Planetary Science Letters 300 (1-2), 152-163. https://doi.org/10.1016/j.epsl.2010.10.001.

Bottke W.F., Nesvornỳ D., Vokrouhlický D., Morbidelli A., 2010. The irregular satellites: The most collisionally evolved populations in the Solar System. The Astronomical Journal 139 (3), 994-1014. https://doi.org/10.1088/0004$6256 / 139 / 3 / 994$.

Bowring S.A., Housh T., 1995. The Earth's early evolution. Science 269 (5230), 1535-1540. https://doi.org/10.1126/ science.7667634.

Bowring S.A., Williams I.S., 1999. Priscoan (4.00-4.03 Ga) orthogneisses from northwestern Canada. Contributions to Mineralogy and Petrology 134 (1), 3-16. https://doi.org/10.1007/s004100050465.

Brenna M., Cronin S.J., Smith I.E.M., Sohn Y.K., Maas R., 2012. Spatio-temporal evolution of a dispersed magmatic system and its implications for volcano growth, Jeju Island Volcanic Field, Korea. Lithos 148, 337-352. https://doi.org/ 10.1016/j.lithos.2012.06.021.

Bunge H.P., Richards M.A., Baumgardner J.R., 1996. Effect of depth-dependent viscosity on the planform of mantle convection. Nature 379 (6564), 436-438. https://doi.org/10.1038/379436a0.

Caro G., Bourdon B., Birck J., Moorbath S., 2003. ${ }^{146} \mathrm{Sm}-{ }^{142} \mathrm{Nd}$ evidence from Isua metamorphosed sediments for early differentiation of the Earth's mantle. Nature 423 (6938), 428-432. https://doi.org/10.1038/nature01668.

Chandrasekharam D., Mahoney J.J., Sheth H.C., Duncan R.A., 1999. Elemental and Nd-Sr-Pb isotope geochemistry of flows and dikes from the Tapi rift, Deccan flood basalt province, India. Journal of Volcanology and Geothermal Research 93 (1-2), 111-123. https://doi.org/10.1016/S0377-0273(99)00081-5.

Chen Y., Zhang Y., Graham D., Su S., Deng J., 2007. Geochemistry of Cenozoic basalts and mantle xenoliths in Northeast China. Lithos 96 (1-2), 108-126. https://doi.org/10.1016/j.lithos.2006.09.015.

Choi H.-O., Choi S.H., Yu Y., 2014. Isotope geochemistry of Jeongok basalts, northernmost South Korea: implications for the enriched mantle end-member component. Journal of Asian Earth Sciences 91, 56-68. https://doi.org/10.1016/ j.jseaes.2014.05.010.

Choi S.H., Mukasa S.B., Kwon S.-T., Andronikov A.V., 2006. Sr, Nd, Pb and Hf isotopic compositions of Late Cenozoic alkali basalts in South Korea: Evidence for mixing between the two dominant asthenospheric mantle domains beneath East Asia. Chemical Geology 232 (3-4), 134-151. https://doi.org/10.1016/j.chemgeo.2006.02.014.

Chou C.L., 1978. Fractionation of siderophile elements in the Earth 's upper mantle. In: Lunar and Planetary Science Conference Proceedings, vol. 9, p. 219-230.

Chuvashova I., Rasskazov S., Sun Yi-min, Yang Chen, 2017b. Origin of melting anomalies in the Japan-Baikal corridor of Asia at the latest geodynamic stage: evolution from the mantle transition layer and generation by lithospheric transtension. Geodynamics \& Tectonophysics 8 (3), 435-440. https://doi.org/10.5800/GT-2017-8-3-0256.

Chuvashova I.S., Rasskazov S.V., Yi-min Sun, 2017a. The latest geodynamics in Central Asia: primary and secondary mantle melting anomalies in the context of orogenesis, rifting, and lithospheric plate motions and interactions. Geodynamics \& Tectonophysics 8 (1), 45-80 (in Russian] [Чувашова И.С., Рассказов С.В., Йи-минь Сунь. Новейшая геодинамика Центральной Азии: первичные и вторичные мантийные расплавные аномалии в контексте орогенеза, рифтогенеза и движения-взаимодействия литосферных плит // Геодинамика и тектонофизика. 2017a. T. 8. № 1. C. 45-80]. https://doi.org/10.5800/GT-2017-8-1-0232.

Connelly J.N., Bizzarro M., Krot A.N., Nordlund A., Wielandt D., Ivanova M.A., 2012. The absolute chronology and thermal processing of solids in the solar protoplanetary disk. Science 338 (6107), 651-655. https://doi.org/10.1126/ science.1226919.

Dale C.W., Burton K.W., Greenwood R.C., Gannoun A., Wade J., Wood B.J., Pearson D.G., 2012. Late accretion on the earliest planetesimals revealed by the highly siderophile elements. Science 336 (6077), 72-75. https://doi.org/ 10.1126/science.1214967.

Dale C.W., Kruijer T.S., Burton K.W., 2017. Highly siderophile element and 182W evidence for a partial late veneer in the source of 3.8 Ga rocks from Isua, Greenland. Earth and Planetary Science Letters 458, 394-404. https:// doi.org/10.1016/j.epsl.2016.11.001.

Dhaliwal J.K., Day J.M.D., Moynier F., 2018. Volatile element loss during planetary magma ocean phases. Icarus 300, 249-260. https://doi.org/10.1016/j.icarus.2017.09.002.

Dickin A.P., 2018. Radiogenic Isotope Geology. Third edition. Cambridge University Press, Cambridge, 477 p.

Diwu C., Sun Y., Wilde S.A., Wang H., Dong Z., Zhang H., Wang Q., 2013. New evidence for $\sim 4.45$ Ga terrestrial crust from zircon xenocrysts in Ordovician ignimbrite in the North Qinling Orogenic Belt, China. Gondwana Research 23 (4), 1484-1490. https://doi.org/10.1016/j.gr.2013.01.001.

Fan Q.-C., Chen S.-S., Zhao Y.-W., Zou H.-B., Li N., Sui J.-L., 2014. Petrogenesis and evolution of Quaternary basaltic rocks from the Wulanhada area, North China. Lithos 206-207, 289-302. https://doi.org/10.1016/j.lithos.2014.08.007. 
Gaffney A.M., Borg L.E., 2014. A young solidification age for the lunar magma ocean. Geochimica et Cosmochimica Acta 140, 227-240. https://doi.org/10.1016/j.gca.2014.05.028.

Gao Y., Wei R., Hou Z., Tian Sh., Zhao R., 2008. Eocene high-MgO volcanism in southern Tibet: new constraints for mantle source characteristics and deep processes. Lithos 105 (1-2), 63-72. https://doi.org/10.1016/j.lithos.2008. 02.008 .

Gatinsky Y.G., Rundquist D.V., 2004. Geodynamics of Eurasia: plate tectonics and block tectonics. Geotectonics 38 (1), 1-16.

Granet M., Wilson M., Achauer U., 1995. Imaging a mantle plume beneath the French Massif Central. Earth and Planetary Science Letters 136 (3-4), 281-296. https://doi.org/10.1016/0012-821X(95)00174-B.

Gu Y.J., Dziewonski A.M., Su W., Ekström G., 2001. Models of the mantle shear velocity and discontinuities in the pattern of lateral heterogeneities. Journal of Geophysical Research: Solid Earth 106 (B6), 11169-11199. https://doi.org/ 10.1029/2001JB000340.

Guo Z., Wilson M., Liu J., Mao Q., 2006. Post-collisional, potassic and ultrapotassic magmatism of the northern Tibetan Plateau: Constraints on characteristics of the mantle source, geodynamic setting and uplift mechanisms. Journal of Petrology 47 (6), 1177-1220. https://doi.org/10.1093/petrology/egl007.

Guo Z., Wilson M., Liu J., 2007. Post-collisional adakites in south Tibet: products of partial melting of subductionmodified lower crust. Lithos 96 (1-2), 205-224. https://doi.org/10.1016/j.lithos.2006.09.011.

Hanan B.B., Graham D.W., 1996. Lead and helium isotope evidence from oceanic basalts for a common deep source of mantle plumes. Science 272 (5264), 991-995. https://doi.org/10.1126/science.272.5264.991.

Hart S.R., Gaetani G.A., 2006. Mantle Pb paradoxes: the sulfide solution. Contributions to Mineralogy and Petrology 152 (3), 295-308. https://doi.org/10.1007/s00410-006-0108-1.

Hart S.R., Gerlach D.C., White W.M., 1986. A possible new Sr-Nd-Pb mantle array and consequences for mantle mixing. Geochimica et Cosmochimica Acta 50 (7), 1551-1557. https://doi.org/10.1016/0016-7037(86)90329-7.

Hauri E.H., Whitehead J.A., Hart S.R., 1994. Fluid dynamic and geochemical aspects of entrainment in mantle plumes. Journal of Geophysical Research: Solid Earth 99 (B12), 24275-24300. https://doi.org/10.1029/94JB01257.

He S.P., Li R.S., Wang C., Zhang H.F., Ji W.H., Yu P.S., Gu P.Y., Shi C., 2011. Discovery of $\sim 4.0$ detrital zircons in the Changdu block, North Qiangtang, Tibetan Plateau. Chinese Science Bulletin 56 (7), 647-658. https://doi.org/10.1007/ s11434-010-4320-z.

Hoang N., Flower M.F., Carlson R.W., 1996. Major, trace element, and isotopic compositions of Vietnamese basalts: Interaction of hydrous EM1-rich asthenosphere with thinned Eurasian lithosphere. Geochimica et Cosmochimica Acta 60 (22), 4329-4351. https://doi.org/10.1016/S0016-7037(96)00247-5.

Hoàng N., Flower M.F., Xuân P.T., Quý H.V., Sơn T.T., 2013. Collision-induced basalt eruptions at Pleiku and Buôn Mê Thuột, south-central Viet Nam. Journal of Geodynamics 69, 65-83. https://doi.org/10.1016/j.jog.2012.03.012.

Iizuka T., Horie K., Komiya T., Maruyama S., Hirata T., Hidaka H., Windley B.F., 2006. 4.2 Ga zircon xenocryst in an Acasta gneiss from northwestern Canada: Evidence for early continental crust. Geology 34 (4), 245-248. https:// doi.org/10.1130/G22124.1.

Ji J.Q., Han B.F., Zhu M.F., Chu Z.Y., Liu Y.L., 2006. Cretaceous-Paleogene alkaline magmatism in Tuyon basin, southwest Tianshan mountains: geochronology, petrology and geochemistry. Acta Petrologica Sinica 22 (5), 1324-1340.

Kleine T., Touboul M., Bourdon B., Nimmo F., Mezger K., Palme H., Jacobsen S.B., Yin Q.-Z., Halliday A.N., 2009. Hf-W chronology of the accretion and early evolution of asteroids and terrestrial planets. Geochimica et Cosmochimica Acta 73 (17), 5150-5188. https://doi.org/10.1016/j.gca.2008.11.047.

Kozhevnikov V.M., Seredkina A.I., Solovei O.A., 2014. 3D mantle structure of Central Asia from Rayleigh wave group velocity dispersion. Russian Geology and Geophysics 55 (10), 1239-1247. https://doi.org/10.1016/j.rgg.2014.09.010.

Kreemer C., Holt W.E., Haines A.J., 2003. An integrated global model of present-day plate motions and plate boundary deformation. Geophysical Journal International 154 (1), 8-34. https://doi.org/10.1046/j.1365-246X.2003.01917.x.

Kruijer T.S., Kleine T., Fischer-Gödde M., Sprung P., 2015. Lunar tungsten isotopic evidence for the late veneer. Nature 520 (7548), 534-537. https://doi.org/10.1038/nature14360.

Kuritani T., Kimura J.I., Ohtani E., Miyamoto H., Furuyama K., 2013. Transition zone origin of potassic basalts from Wudalianchi volcano, Northeast China. Lithos 156-159, 1-12. https://doi.org/10.1016/j.lithos.2012.10.010.

Kuz'min M.I., 2014. The Precambrian history of the origin and evolution of the Solar System and Earth. Part 1. Geodynamics \& Tectonophysics 5 (3), 625-640 (in Russian) [Кузьмин М.И. Докембрийская история зарождения и эволюции Солнечной системы и Земли. статья 1 // Геодинамика и тектонофизика. 2014. Т. 5. № 3. C. 625-640]. https://doi.org/10.5800/GT-2014-5-3-0146.

Liu D.Y., Nutman A.P., Compston W., Wu J.S., Shen Q.H., 1992. Remnants of $\geq 3800$ Ma crust in the Chinese part of the Sino-Korean craton. Geology 20 (4), 339-342. https://doi.org/10.1130/0091-7613(1992)020<0339:ROMCIT>2.3. CO;2.

Lustrino M., Wilson M., 2007. The circum-Mediterranean anorogenic Cenozoic igneous province. Earth-Science Reviews 81 (1-2), 1-65. https://doi.org/10.1016/j.earscirev.2006.09.002. 
Marchi S., Canup R.M., Walker R.J., 2018. Heterogeneous delivery of silicate and metal to the Earth by large planetesimals. Nature Geoscience 11 (1), 77-81. https://doi.org/10.1038/s41561-017-0022-3.

Maruyama S., Ebisuzaki T., 2017. Origin of the Earth: A proposal of new model called ABEL. Geoscience Frontiers 8 (2), 253-274. https://doi.org/10.1016/j.gsf.2016.10.005.

Maruyama S., Santosh M., Zhao D., 2007. Superplume, supercontinent, and post-perovskite: mantle dynamics and antiplate tectonics on the core-mantle boundary. Gondwana Research 11 (1-2), 7-37. https://doi.org/10.1016/j.gr. 2006.06.003.

Melluso L., Mahoney J.J., Dallai L., 2006. Mantle sources and crustal input as recorded in high-Mg Deccan Traps basalts of Gujarat (India). Lithos 89 (3-4), 259-274. https://doi.org/10.1016/j.lithos.2005.12.007.

Menzies M.A. (Ed.), 1990. Continental Mantle. Clarendon Press, Oxford, 177 p.

Molnar P., Tapponnier P., 1975. Cenozoic tectonics of Asia: effects of a continental collision. Science 189 (4201), 419-426. https://doi.org/10.1126/science.189.4201.419.

Morbidelli A., Nesvorny D., Laurenz V., Marchi S., Rubie D.C., Elkins-Tanton L., Wieczorek M., Jacobson S., 2018. The timeline of the Lunar bombardment - revisited. Icarus 305, 262-276. https://doi.org/10.1016/j.icarus.2017. 12.046 .

Morgan W.J., 1971. Convection plumes in the lower mantle. Nature 230 (5288), 42-43. https://doi.org/10.1038/ $230042 \mathrm{a} 0$

Morino P., Caro G., Reisberg L., 2018. Differentiation mechanisms of the early Hadean mantle: insights from combined ${ }^{176} \mathrm{Hf}-142,143 \mathrm{Nd}$ signatures of Archean rocks from the Saglek Block. Geochimica et Cosmochimica Acta 240, 43-63. https://doi.org/10.1016/j.gca.2018.08.026.

Müller R.D., Sdrolias M., Gaina C., Roest W.R., 2008. Age, spreading rates, and spreading asymmetry of the world's ocean crust. Geochemistry, Geophysics, Geosystems 9 (4), Q04006. https://doi.org/10.1029/2007GC001743.

Murphy D.T., Kamber B.S., Collerson K.D., 2003. A refined solution to the first terrestrial Pb-isotope paradox. Journal of Petrology 44 (1), 39-53. https://doi.org/10.1093/petrology/44.1.39.

O'Neil J., Carlson R.W., Francis D., Stevenson R.K., 2008. Neodymium-142 evidence for Hadean mafic crust. Science 321 (5897), 1828-1831. https://doi.org/10.1126/science.1161925.

Park K.H., Park J.B., Cheong C.S., Oh C.W., 2005. Sr, Nd and Pb isotopic systematics of the Cenozoic basalts of the Korean Peninsula and their implications for the Permo-Triassic continental collision boundary. Gondwana Research 8 (4), 529-538. https://doi.org/10.1016/S1342-937X(05)71153-9.

Parman S.W., 2007. Helium isotopic evidence for episodic mantle melting and crustal growth. Nature 446 (7138), 900-903. https://doi.org/10.1038/nature05691.

Paul D.K., Ray A., Das B., Patil S.K., Biswas S.K., 2008. Petrology, geochemistry and paleomagnetism of the earliest magmatic rocks of Deccan Volcanic Province, Kutch, Northwest India. Lithos 102 (1-2), 237-259. https://doi.org/ 10.1016/j.lithos.2007.08.005.

Peng Z.X., Mahoney J., Hooper P., Harris C., Beane J., 1994. A role for lower continental crust in flood basalt genesis? Isotopic and incompatible element study of the lower six formations of the western Deccan Traps. Geochimica et Cosmochimica Acta 58 (1), 267-288. https://doi.org/10.1016/0016-7037(94)90464-2.

Peng Z.X., Mahoney J.J., Vanderkluysen L., Hooper P.R., 2014. Sr, Nd and Pb isotopic and chemical compositions of central Deccan Traps lavas and relation to southwestern Deccan stratigraphy. Journal of Asian Earth Sciences 84, 83-94. https://doi.org/10.1016/j.jseaes.2013.10.025.

Rasskazov S.V., Bowring S.A., Hawsh T., Demonterova E.I., Logachev N.A., Ivanov A.V., Saranina E.V., Maslovskaya M.N., 2002. The $\mathrm{Pb}, \mathrm{Nd}$, and $\mathrm{Sr}$ isotope systematics in heterogeneous continental lithosphere above the convecting mantle domain. Doklady Earth Sciences 387A (9), 1056-1059.

Rasskazov S.V., Brandt S.B., Brandt I.S., 2010. Radiogenic Isotopes in Geologic Processes. Springer, 306 p. https:// doi.org/10.1007/978-90-481-2999-7.

Rasskazov S.V., Chuvashova I.S., 2013. Global and regional expressions of the latest geodynamic stage. Bulletin of Moscow Society of Naturalists, Geological section 88 (4), 21-35 (in Russian) [Рассказов С.В., Чувашова И.С. Глобальное и региональное выражение новейшего геодинамического этапа // Бюллетень Московского общества испытателей природы. Отдел геологический. 2013. Т. 88. № 4. С. 21-35].

Rasskazov S.V., Chuvashova I.S., 2018. Volcanism and Transtension in the Northeastern Baikal Rift System. Academic Publishing House «GEO», Novosibirsk, 384 p. (in Russian] [Рассказов С.В., Чувашова И.С. Вулканизм и транстенсия на северо-востоке Байкальской рифтовой системы. Новосибирск: Академическое изд-во «Гео», 2018 384 c.]. https://doi.org/10.21782/B978-5-6041446-3-3.

Rasskazov S.V., Chuvashova I.S., Mikolaichuk A.V., Sobel E.R., Yasnygina T.A., Fefelov N.N., Saranina E.V., 2015. Lateral change of sources for the Cretaceous - Paleogene magmatism of the Tian Shan. Petrology 23 (3), 281-308. https:// doi.org/10.1134/S0869591115010038.

Rasskazov S.V., Chuvashova I.S., Sun Yi-min, Yang Chen, Xie Zhenhua, Yasnygina T.A., Saranina E.V., Zhengxing Fang 2016. Sources of Quaternary potassic volcanic rocks from Wudalianchi, China: Control by transtension at the lithosphere-asthenosphere boundary layer. Geodynamics \& Tectonophysics 7 (4), 555-592. https://doi.org/10.5800/ GT-2016-7-4-0223. 
Rasskazov S.V., Mel'nikov O.A., Rybin A.V., Gur'yanov V.A., Yasnygina T.A., Brandt I.S., Brandt S.B., Saranina E.V., Maslovskaya M.N., Fefelov N.N., Zharov A.E., 2005. Spatial change of deep sources for Cenozoic volcanic rocks in western coast of South Sakhalin. Tikhookeanskaya Geologiya 24 (2), 10-32 (in Russian) [Рассказов С.В., Мельников О.А., Рыбин А.В., Гурьянов В.А., Ясныгина Т.А., Брандт И.С., Брандт С.Б., Саранина Е.В., Масловская М.Н., Фефелов Н.Н., Жаров А.Э. Пространственная смена глубинных источников кайнозойских вулканических пород западного побережья Южного Сахалина // Тихоокеанская геология. 2005. Т. 24. № 2. С. 10-32].

Rasskazov S., Sun Yi-min, Chuvashova I., Yasnygina T., Yang Chen, Xie Zhenhua, Saranina E., Gerasimov N., Vladimirova T., 2019. Origin of sources for potassic rocks from Wudalianchi, Northeast China: Case study of the Longmenshan and Molabushan volcanoes. Geochemica Acta (in press).

Rasskazov S.V., Yasnygina T.A., Chuvashova I.S., 2014. Mantle sources of the cenozoic volcanic rocks of East Asia: derivatives of slabs, the sublithospheric convection, and the lithosphere. Russian Journal of Pacific Geology 8 (5), 360-378. https://doi.org/10.1134/S1819714014050030.

Rubie D.C., Frost D.J., Mann U., Asahara Y., Nimmo F., Tsuno K., Kegler P., Holzheid A., Palme H., 2011. Heterogeneous accretion, composition and core - mantle differentiation of the Earth. Earth and Planetary Science Letters 301 (1-2), 31-42. https://doi.org/10.1016/j.epsl.2010.11.030.

Rudolph M.L., Lekić V., Lithgow-Bertelloni C., 2015. Viscosity jump in Earth's mid-mantle. Science 350 (6266), 13491352. https://doi.org/10.1126/science.aad1929.

Sakuyama T., Nagaoka S., Miyazaki T., Chang Q., Takahashi T., Hirahara Y., Senda R., Itaya T., Kimura J., Ozawa K., 2014. Melting of the uppermost metasomatized asthenosphere triggered by fluid fluxing from ancient subducted sediment: Constraints from the Quaternary basalt lavas at Chugaryeong Volcano, Korea. Journal of Petrology 55 (3), 499-528. https://doi.org/10.1093/petrology/egt074.

Sandwell D.T., Anderson D., Wessel P., 2005. Global tectonic maps. In: G.L. Foulger, J.H. Natland, D.C. Presnall, D.L. Anderson (Eds.), Plates, plumes and paradigms. Geological Society of America Special Paper, vol. 388, p. 1-10. https://doi.org/10.1130/0-8137-2388-4.1.

Sen G., Bizimis M., Das R., Paul D.K., Ray A., Biswas S., 2009. Deccan plume, lithosphere rifting, and volcanism in Kutch, India. Earth and Planetary Science Letters 277 (1-2), 101-111. https://doi.org/10.1016/j.epsl.2008.10.002.

Şengör A.M., Natal'in B.A., 1996. Paleotectonics of Asia: fragments of a synthesis. In: A. Yin, M. Harrison (Eds.), The tectonic evolution of Asia. Cambridge University Press, Cambridge, p. 486-640.

Sheth H.C., Melluso L., 2008. The Mount Pavagadh volcanic suite, Deccan Traps: geochemical stratigraphy and magmatic evolution. Journal of Asian Earth Sciences 32 (1), 5-21. https://doi.org/10.1016/j.jseaes.2007.10.001.

Snape J.F., Nemchin A.A., Bellucci J.J., Whitehouse M.J., Tartèse R., Barnes J.J., Anand M., Crawford I.A., Joy K.H., 2016. Lunar basalt chronology, mantle differentiation and implications for determining the age of the Moon. Earth and Planetary Science Letters 451, 149-158. https://doi.org/10.1016/j.epsl.2016.07.026.

Sobel E.R., Arnaud N., 2000. Cretaceous-Paleogene basaltic rocks of the Tuyon basin, NW China and the Kyrgyz Tian Shan: the trace of a small plume. Lithos 50 (1-3), 191-215. https://doi.org/10.1016/S0024-4937(99)00046-8.

Sobolev A.V., Hofmann A.W., Sobolev S.V., Nikogosian I.K., 2005. An olivine-free mantle source of Hawaiian shield basalts. Nature 434 (7033), 590-597. https://doi.org/10.1038/nature03411.

Song Y., Frey F.A., Zhi H., 1990. Isotopic characteristics of Hannuoba basalts, eastern China: implications for their petrogenesis and the composition of subcontinental mantle. Chemical Geology 88 (1-2), 35-52. https://doi.org/ 10.1016/0009-2541(90)90102-D.

Sprung P., Kleine T., Scherer E.E., 2013. Isotopic evidence for chondritic $\mathrm{Lu} / \mathrm{Hf}$ and $\mathrm{Sm} / \mathrm{Nd}$ of the Moon. Earth and Planetary Science Letters 380, 77-87. https://doi.org/10.1016/j.epsl.2013.08.018.

Stacey J.S., Kramers J.D., 1975. Approximation of terrestrial lead isotope evolution by a two-stage model. Earth and Planetary Science Letters 26 (2), 207-221. https://doi.org/10.1016/0012-821X(75)90088-6.

Tatsumi Y., Maruyama S., Nohda S., 1990. Mechanism of backarc opening in the Japan Sea: role of asthenospheric injection. Tectonophysics 181 (1-4), 299-306. https://doi.org/10.1016/0040-1951(90)90023-2.

Tatsumi Y., Shukuno H., Yoshikawa M., Chang Q., Sato K., Lee M.W., 2005. The petrology and geochemistry of volcanic rocks on Jeju Island: plume magmatism along the Asian continental margin. Journal of Petrology 46 (3), 523-553. https://doi.org/10.1093/petrology/egh087.

Tatsumoto M., 1978. Isotopic composition of lead in oceanic basalt and its implication to mantle evolution. Earth and Planetary Science Letters 38 (1), 63-87. https://doi.org/10.1016/0012-821X(78)90126-7.

Tatsumoto M., Basu A.R., Wankang H., Junwen W., Xie G., 1992. Sr, Nd, and Pb isotopes of ultramaphic xenoliths in volcanic rocks of Eastern China: enriched components EMI and EMII in subcontinental lithosphere. Earth and Planetary Science Letters 113 (1-2), 107-128. https://doi.org/10.1016/0012-821X(92)90214-G.

Touboul M., Puchtel I.S., Walker R.J., 2012. ${ }^{182} \mathrm{~W}$ evidence for long-term preservation of early mantle differentiation products. Science 335 (6072), 1065-1069. https://doi.org/10.1126/science.1216351.

Tucker J.M., Mukhopadhyay S., 2014. Evidence for multiple magma ocean outgassing and atmospheric loss episodes from mantle noble gases. Earth and Planetary Science Letters 393, 254-265. https://doi.org/10.1016/j.epsl.2014. 02.050 . 
Turner S., Arnald N., Liu J., Rogers N., Hawkesworth C., Harris N., Kelley S., Van Calsteren P., Deng W., 1996. Post-collision, shoshonitic volcanism on the Tibetan Plateau: Implications for convective thinning of the lithosphere and the source of ocean island basalts. Journal of Petrology 37 (1), 45-71. https://doi.org/10.1093/petrology/37.1.45.

Wade J., Wood B.J., 2005. Core formation and the oxidation state of the Earth. Earth and Planetary Science Letters 236 (1-2), 78-95. https://doi.org/10.1016/j.epsl.2005.05.017.

Wade J., Wood B.J., 2016. The oxidation state and mass of the Moon-forming impactor. Earth and Planetary Science Letters 442, 186-193. https://doi.org/10.1016/j.epsl.2016.02.053.

Wee S.M., 1999. Geochemistry and petrogenesis of Jeungok basalts in mid-Korean peninsula. Journal of Mineralogy, Petrology and Economic Geology 94 (6), 222-240. https://doi.org/10.2465/ganko.94.222.

White W.M., 2015. Probing the Earth's deep interior through geochemistry. Geochemical Perspectives 4 (2), 95-251. https://doi.org/10.7185/geochempersp.4.2.

Wilde S.A., Valley J.W., Peck W.H., Graham C.M., 2001. Evidence from detrital zircons for the existence of continental crust and oceans on the Earth 4.4 Gyr ago. Nature 409 (6817), 175-178. https://doi.org/10.1038/35051550.

Willbold M., Elliott T., Moorbath S., 2011. The tungsten isotopic composition of the Earth's mantle before the terminal bombardment. Nature 477 (7363), 195-199. https://doi.org/10.1038/nature10399.

Wood B.J., Halliday A.N., Rehkämper M., 2010. Volatile accretion history of the Earth. Nature 467 (7319), E6-E7. https://doi.org/10.1038/nature09484.

Wood B.J., Walter M.J., Wade J., 2006. Accretion of the Earth and segregation of its core. Nature 441 (7095), 825-833. https://doi.org/10.1038/nature04763.

Xu Z., Zheng Y.F., 2017. Continental basalts record the crust-mantle interaction in oceanic subduction channel: A geochemical case study from eastern China. Journal of Asian Earth Sciences 145, 233-259. https://doi.org/ 10.1016/j.jseaes.2017.03.010.

Yanovskaya T.B., Kozhevnikov V.M., 2003. 3D S-wave velocity pattern in the upper mantle beneath the continent of Asia from Rayleigh wave data. Physics of the Earth and Planetary Interiors 138 (3-4), 263-278. https://doi.org/ 10.1016/S0031-9201(03)00154-7.

Yoshida M., 2010. Preliminary three-dimensional model of mantle convection with deformable, mobile continental lithosphere. Earth and Planetary Science Letters 295 (1-2), 205-218. https://doi.org/10.1016/j.epsl.2010.04.001.

Yoshida M., Santosh M., 2011. Supercontinents, mantle dynamics and plate tectonics: a perspective based on concepttual vs. numerical models. Earth-Science Reviews 105 (1-2), 1-24. https://doi.org/10.1016/j.earscirev.2010. 12.002 .

Zartman R.E., Futa K., Peng Z.C., 1991. A comparison of Sr-Nd-Pb isotopes in young and old continental lithospheric mantle: Patagonia and Eastern China. Australian Journal of Earth Sciences 38 (5), 545-557. https://doi.org/ 10.1080/08120099108727990.

Zatman S., Gordon R.G., Mutnuri K., 2005. Dynamics of diffuse oceanic plate boundaries: insensitivity to rheology. Geophysical Journal International 162 (1), 239-248. https://doi.org/10.1111/j.1365-246X.2005.02622.x.

Zhang M., Guo Z., 2016. Origin of Late Cenozoic Abaga-Dalinuoer basalts, eastern China: Implications for a mixed pyroxenite-peridotite source related with deep subduction of the Pacific slab. Gondwana Research 37, 130-151. https://doi.org/10.1016/j.gr.2016.05.014.

Zhang M., Guo Z., Liu J., Liu G., Zhang L., Lei M., Zhao W., Ma L., Sepe V., Ventura G. 2018. The intraplate Changbaishan volcanic fild (China/North Korea): A review on eruptive history, magma genesis, geodynamic signifiance, recent dynamics and potential hazards. Earth-Science Reviews 187, 19-52. https://doi.org/10.1016/j.earscirev.2018. 07.011 .

Zhang M., Suddaby P., Thompson R.N., Thirlwall M.F., Menzies M.A., 1995. Potassic volcanic rocks in NE China: geochemical constraints on mantle source and magma genesis. Journal of Petrology 36 (5), 1275-1303. https:// doi.org/10.1093/petrology/36.5.1275.

Zhang Z., Xiao X., Wang J., Wang Y., Kusky T.M., 2008. Post-collisional Plio-Pleistocene shoshonitic volcanism in the western Kunlun Mountains, NW China: Geochemical constraints on mantle source characteristics and petrogenesis. Journal of Asian Earth Sciences 31 (4-6), 379-403. https://doi.org/10.1016/j.jseaes.2007.06.003.

Zhao D., 2009. Multiscale seismic tomography and mantle dynamics. Gondwana Research 15 (3-4), 297-323. https:// doi.org/10.1016/j.gr.2008.07.003.

Zhi X., Song Y., Frey F.A., Feng J., Zhai M., 1990. Geochemistry of Hannuoba basalts, eastern China: constraints on the origin of continental alkalic and tholeiitic basalt. Chemical Geology 88 (1-2), 1-33. https://doi.org/10.1016/00092541(90)90101-C.

Zindler A., Hart S., 1986. Chemical geodynamics. Annual Review of Earth and Planetary Sciences 14, 493-571. https:// doi.org/10.1146/annurev.ea.14.050186.002425.

Zonenshain L.P., Kuzmin M.I., Bocharova N.Y., 1991. Hot-field tectonics. Tectonophysics 199 (2-4), 165-192. https:// doi.org/10.1016/0040-1951(91)90171-N. 
Zou H., Zindler A., Xu X., Qi Q., 2000. Major, trace element, and Nd, Sr, and Pb isotope studies of Cenozoic basalts in SE China: mantle sources, regional variations, and tectonic significance. Chemical Geology 171 (1-2), 33-47. https://doi.org/10.1016/S0009-2541(00)00243-6.

\section{Сергей Васильевич Рассказов}

докт. геол.-мин. наук, профессор, зав. лабораторией

Институт земной коры СО РАН

664033, Иркутск, ул. Лермонтова, 128, Россия

Иркутский государственный университет, геологический факультет 664003, Иркутск, ул. Ленина, 3, Россия

凶e-mail: rassk@crust.irk.ru

(iD) https://orcid.org/0000-0001-9084-1652

\section{Ирина Сергеевна Чувашова}

канд. геол.-мин. наук, с.н.с.

Институт земной коры СО РАН

664033, Иркутск, ул. Лермонтова, 128, Россия

Иркутский государственный университет, геологический факультет 664003, Иркутск, ул. Ленина, 3, Россия

e-mail: chuvashova@crust.irk.ru

(iD) https://orcid.org/0000-0002-1582-4753

\section{Татьяна Александровна Ясныгина}

канд. геол.-мин. наук, с.н.с.

Институт земной коры СО РАН

664033, Иркутск, ул. Лермонтова, 128, Россия

凶e-mail: ty@crust.irk.ru

\section{Сунь Йи-минь}

научный сотрудник.

Институт вулканов и минеральных источников

Хэйлунцзянской академии наук

164155, Удаляньчи, Хэйлунцзян, Китай

ه e-mail:894817259@qq.com

\section{Елена Владимировна Саранина}

канд. геол.-мин. наук, с.н.с.

Институт земной коры СО РАН

664033, Иркутск, ул. Лермонтова, 128 , Россия

凶e-mail: e_v_sar@mail.ru

\section{Sergei V. Rasskazov}

Doctor of Geology and Mineralogy, Professor, Head of Laboratory

Institute of the Earth's Crust, Siberian Branch of RAS

128 Lermontov street, Irkutsk 664033, Russia

Irkutsk State University, Geological Faculty

3 Lenin street, Irkutsk 664003, Russia

\section{Irina S. Chuvashova}

Candidate of Geology and Mineralogy, Senior Researcher

Institute of the Earth's Crust, Siberian Branch of RAS

128 Lermontov street, Irkutsk 664033, Russia

Irkutsk State University, Geological Faculty

3 Lenin street, Irkutsk 664003, Russia

\section{Tatiana A. Yasnygina}

Candidate of Geology and Mineralogy, Senior Researcher

Institute of the Earth's Crust, Siberian Branch of RAS

128 Lermontov street, Irkutsk 664033, Russia

\section{Sun Yi-min}

Researcher

Institute of Volcano and Mineral Spring,

Heilongjiang Academy of Science

Wudalianchi 164155, Heilongjiang, China

\section{Elena V. Saranina}

Candidate of Geology and Mineralogy, Senior Researcher

Institute of the Earth's Crust, Siberian Branch of RAS

128 Lermontov street, Irkutsk 664033, Russia 